\title{
The influence of tidal straining and wind on suspended matter and phytoplankton distribution in the Rhine outflow region
}

\author{
J.C.A. Joordens ${ }^{\mathrm{a}}$, A.J. Souza ${ }^{\mathrm{b}, *}$, A. Visser ${ }^{\mathrm{c}}$ \\ a AIDEnvironment, Donker Curtiusstrat 7-523, 1051 JL Amsterdam, The Netherlands \\ ${ }^{\mathrm{b}}$ Proudman Oceanographic Laboratory, Bidston Observatory, Bidston Hill, \\ Prenton CH43 7RA, UK \\ ${ }^{\mathrm{c}}$ Danish Institute of Fisheries Research, Charlottenlund Castle, DK 2920 Charlottenlund, Denmark
}

Received 17 December 1996; received in revised form 31 August 1999; accepted 14 June 2000

\begin{abstract}
To study the short-term effects of the physical environment on phytoplankton dynamics in the Rhine outflow area, changes in salinity, beam attenuation and phytoplankton distribution were observed in a series of high resolution measurements. During periods of weak wind and neap tide (low turbulent kinetic energy, TKE), the system was dominated by tidal straining that resulted in semi-diurnal oscillations in stratification. Phytoplankton was kept in resuspension at about 10-15 m depth. Subsequent strong wind and tidal mixing (high TKE) broke down stratification, enhanced horizontal gradients and suppressed estuarine transport. It is hypothesised that during low TKE, tidal straining and frontal circulation determined the phytoplankton distribution; and at high TKE, input by wind and tide enhanced conditions for growth, which resulted in a bloom in the surface layer of the Rhine Plume, where light and nutrients were available. (C) 2001 Elsevier Science Ltd. All rights reserved.
\end{abstract}

Keywords: Tidal straining; Dutch coast; North Sea; Freshwater influence; Algal blooms; Suspended particulate matter

\section{Introduction}

The shallow Dutch coastal area is a dynamic and highly variable environment, strongly influenced by the outflow of the River Rhine. Erosion processes and human activities in the Rhine watershed result in an elevated load of suspended particulate matter (SPM) and plant nutrients in the river and coastal zone (Fransz, 1986; Visser, 1993). In addition, the density gradients, which

\footnotetext{
*Corresponding author. Tel.: 44-151-653-8633; fax: 44-151-653-6269.

E-mail address: ajso@pol.ac.uk (A.J. Souza).
} 
are mainly associated with the freshwater outflow, significantly affect the coastal circulation patterns (Van der Giessen et al., 1990; De Ruijter et al., 1992). The Rhine outflow area can be divided into two zones (Van Alphen et al., 1988): the near-field zone dominated by buoyant spreading of the river water and alongshore tidal advection of the plume, and the far field zone or coastal current area, where the effect of rotation becomes important, generating a typical buoyancy coastal current flowing with the coast on its right. Previous studies of this area (Simpson and Souza, 1995; Souza and James, 1996) suggest that the physical processes are, at least to a first order, two-dimensional: cross-shore and depth $(x-z)$. The water column stability is a result of competition between the buoyancy input of the horizontal density gradients, generated by the Rhine outflow, and the stirring energy from wind waves and tides. At times of stratification and reduced mixing, the occurrence of strong semi-diurnal oscillations in stability, superimposed on a mean stratification, is a persistent feature in the Rhine outflow area. This is the result of tidal straining; i.e. differential bottom and surface tidal advection of the density gradients, which causes the water to switch from stratified to homogeneous conditions within a tidal cycle. The difference in tidal advection is caused by the decoupling of the two layers during stratification, and the resulting change in tidal ellipses of top and bottom layer: from degenerate at the top and anticlockwise in the bottom layer, during homogeneous conditions, to a relatively larger clockwise ellipse in the top and a relatively smaller anti-clockwise ellipse in the bottom layer, during stratification (Souza and James, 1996).

The physical regimes of shallow coastal zones, such as the Rhine outflow area, are different from those of the open ocean, and the connections between physical variability and phytoplankton dynamics are less well established for coastal systems (Koseff et al., 1993). Coastal regimes can be characterised by shallow water depth, strong influence of river run-off and, often, high frequency variability over periods of hours and days. When studying phytoplankton dynamics in coastal systems, emphasis can be placed on the effect of the chemical environment, namely the flux and concentrations of nutrients stimulating or limiting phytoplankton growth (Fransz, 1986; Schaub and Gieskes, 1991; Malej et al., 1995). However, Tett et al. (1993) suggest that in the Southern North Sea, the effects of the physical environment on phytoplankton dynamics are relatively more important. Wind and tidal stirring together with fresh water input determine circulation patterns, location, strength and variability of haline stratification and thus the position of the pycnocline and the thickness of the upper mixed layer, while nutrient availability and zooplankton grazing determine phytoplankton peak biomass.

The objective of the present study was to investigate the short-term effects of the physical environment on suspended particulate matter (SPM) and phytoplankton distribution in the Rhine outflow area. Following the hypothesis of Tett et al. (1993), zooplankton grazing and nutrients were disregarded as major factors influencing SPM and phytoplankton distribution. Nutrients do not appear to be a limiting factor in this region due to the enrichment from riverine waters, e.g. Simpson et al. (1993) found concentrations of nitrogen greater than $30 \mu \mathrm{M}$ which were highly correlated with the brackish water. Hence, this study is focussed on the effects of the physical environment on phytoplankton distribution. Following the conclusions of Simpson and Souza (1995) of two-dimensionality and high-frequency variability, the changes in salinity, phytoplankton and SPM distribution were studied over short time scales (hours-days) in a slice portion of the coastal current zone. The Noordwijk transect in the coastal current zone was chosen, in order to avoid the along-shore advection of the river plume and strong diffusive forces. The undulating 
SEAROVER provided one vertical profile every $100 \mathrm{~m}$ while steaming at a speed of 6 knots, resulting in a quasi-synoptic $20 \mathrm{~km}$ slice approximately every $2 \mathrm{~h}$.

\section{Material and methods}

During a two-week experiment from 6 to 15 April (Julian days 96-105) 1994 on board R.V. "Mitra" a survey was carried out with the undulating SEAROVER and attached CTD, which contained also a transmissometer and a fluorometer. Details about the SEAROVER system are given in Bauer et al. (1985). The survey consisted of a repeated $20 \mathrm{~km}$ transect in cross-shore direction, covering the width of the Rhine plume. The chosen transect off Noordwijk (Fig. 1) stretched from 5 (NW5) to $25 \mathrm{~km}$ (NW25) offshore, and water depth varied from approximately 15 to $24 \mathrm{~m}$. The maximum depth that could be safely sampled with SEAROVER was $12-19 \mathrm{~m}$, depending on water depth. Each transect took about $2 \mathrm{~h}$. The survey was carried out continuously (aslong as weather conditions permitted and included two contrasting periods: a calm weather, neap tide period with (days 96-98) weak wind and wave energy, and a spring tide (days 101-103) coinciding with strong wind and wave mixing. Wind and tidal energy together can be included in the term turbulent kinetic energy (TKE), which can be defined as the energy in a system available for mixing. Thus we call the first period a low turbulent kinetic energy (TKE) period, and the second, a high TKE period.

The SEAROVER sensors were calibrated as follows: the temperature sensor was calibrated using a reversible thermometer; conductivity was calibrated against salinity, determined at a bath temperature of $24^{\circ} \mathrm{C}$ using $\mathrm{P}$ series standard seawater and a Guildline Autosal $8400 \mathrm{~A}$ salinometer. The transmissometer measures beam attenuation, which can be regarded as proportional to SPM (Jago et al., 1993); the fluorometer measures chlorophyll-a fluorescence, which can be regarded as representative for the pigment chlorophyll-a concentration in phytoplankton. For calibration of chlorophyll fluorescence, water samples were filtered on board using Whatman $\mathrm{GF} / \mathrm{C}$ filters. The filters were then stored at temperatures below $-18^{\circ} \mathrm{C}$. Chlorophyll-a and phaeopigments were extracted according to Gieskes and Kraay (1984) and analysed by HPLC method with a 85-100\% acetone-water gradient using a reversed phase RP18 Novopack column (waters) in a Pectra Physica chromatography station. Chlorophyll-a was detected with a Perkin Elmer LS-LS-2B fluorimeter (excitation: 410-430 nm, emission: > $530 \mathrm{~nm}$ ). The water samples were taken at daily intervals around noon (so no day night variation can be inferred), the resulting formula was used to convert fluorescence (fl) to chlorophyll-a concentration $\left(\mu \mathrm{g} 1^{-1}\right)$, following Mills and Tett (1990) is

$$
\text { Chlorophyll-a }=9.446+3.382 \times 10^{-4} \times 10^{(\mathrm{fl})} \quad \text { with } n=6 \text { and } R^{2}=0.8 \text {. }
$$

To calibrate beam attenuation against SPM concentration, water samples were filtered on board through pre-weighted Whatman $\mathrm{GF} / \mathrm{C}$ filters, and filters stored below $18^{\circ} \mathrm{C}$. Unfortunately, the filters slightly thawed during transport to the laboratory, and could not be used for further analysis. Therefore, in the results, graphs of beam attenuation are presented instead of SPM concentration. 


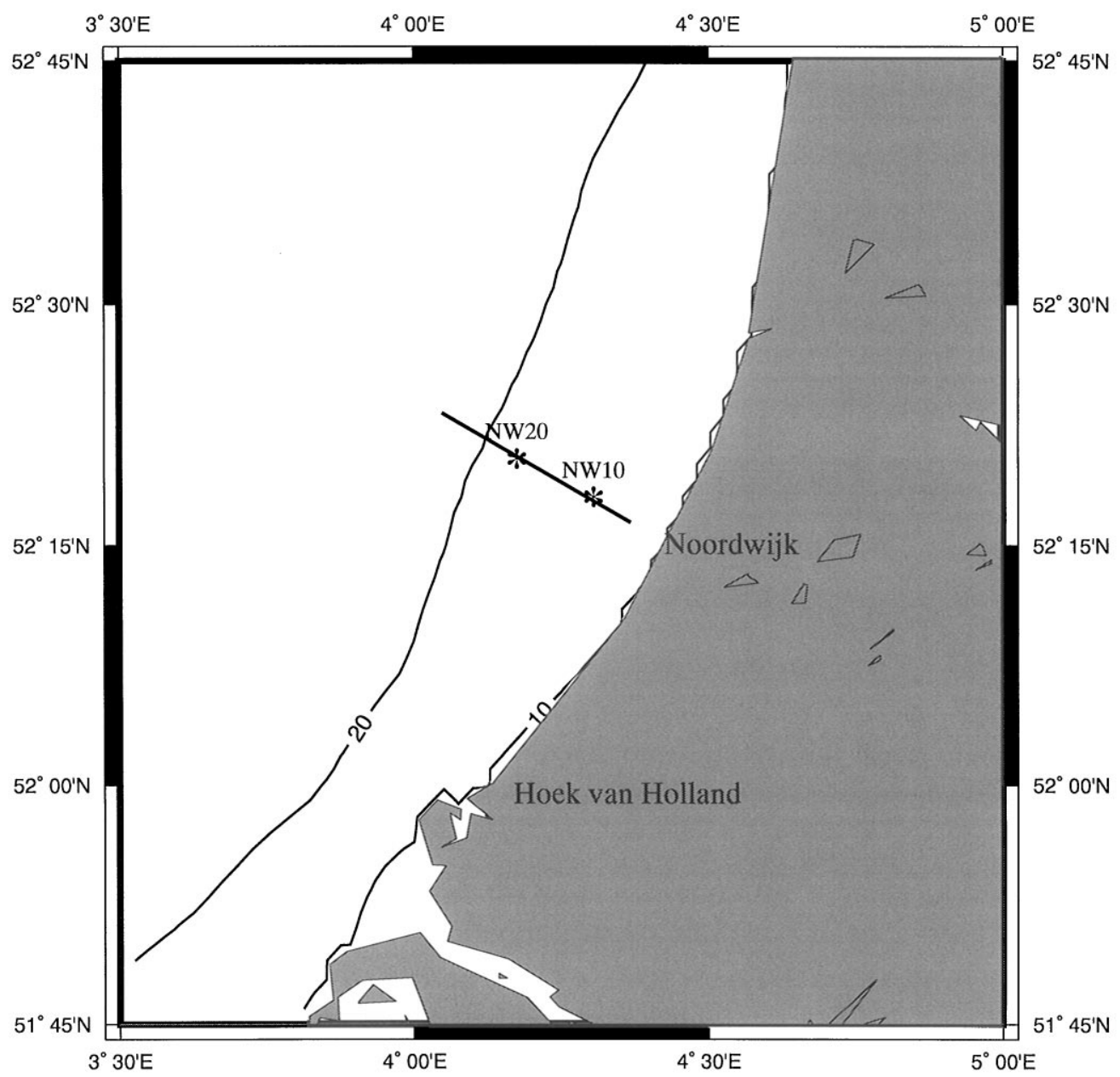

Fig. 1. Study area showing the SEAROVER Nordwijk transect. The transect runs from $5 \mathrm{~km}$ offshore (NW5) to $25 \mathrm{~km}$ offshore (NW25) and moorings at $10 \mathrm{~km}$ from the coast (NW10) and $20 \mathrm{~km}$ from the coast (NW20).

Time series of velocity profiles were obtained using two high-frequency (1.2 MHz RDI) bottom mounted acoustic Doppler current profilers (ADCP) (Fig. 1): a Broad Band ADCP at $10 \mathrm{~km}$ offshore from Noordwijk (NW10) and a Narrow Band ADCP at $20 \mathrm{~km}$ offshore from Noordwijk (NW20). Wind velocity, wind direction, significant wave height and water level were measured at the Meetpost Noordwijk form close to NW10. Rhine discharge was measured at Lobith. Phytoplankton was sampled at two depths (surface and 15 m) at NW10 on days 101, 102 and 105. Settling velocities were determined with SETCOLS (Bienfang, 1981). Species composition was determined in samples fixated with $0.1 \%$ paraformaldehyde using an inverted microscope. Phytoplankton settling velocities were immediately measured on board with SETCOLS (Bienfang, 1981), using fresh samples from day 101. 


\section{Observations}

\subsection{Time series and phytoplankton}

Time series of wave height and water level at Meetpost Noordwijk, Rhine discharge at Lobith and surface irradiance (PAR) at NW10 and NW20 are presented in Fig. 2. Time series of wind components and wind vectors can be observed in Fig. 3a-c. Wind mixing energy and tidal mixing energy (Fig. 3d and e) are calculated using measured wind and ADCP data with the coefficients suggested by Simpson and Bowers (1981). The wind mixing energy rate was high between Julian day 94 and 96, just before the start of the SEAROVER surveys. From day 96 until day 98, relative calm weather was observed, with wind coming from the south. Stormy weather on day 99 is represented as a peak in the wind mixing energy and it decreased on day 100. During the second part of the experiment, from day 101 till 104 the wind mixing energy was relatively high and increasing (10-15 $\mathrm{m} \mathrm{s}^{-1}$ from the north) to the point that the experiment had to be interrupted on day 103 and 104. On day 105 the wind had somewhat abated and it was possible to sail again. The tidal mixing energy exhibited a typical spring-neap cycle with low velocities on days 96-99, representing the neap period. The tidal mixing energy started to increase on day 99, showing the influence of the springs, and then started to decrease on day 105. Phytoplankton species composition and cell numbers are represented in Table 1, unfortunately, there was no phytoplankton samples collected for identification on days 96-98, so we do not know if there was a change in the dominant organism, which might have given us an insight into possible plankton advective processes. It is interesting to note that the dominant species, Rhizosolenia delicatula, is a large diatom that will withstand the high turbulence better than other organisms, such as some species of dinoflagellates. This may be an important factor in explaining the wax and wane of Dinophysis accuminata in Dutch coastal waters (Zevenboom et al., 1991). The settling velocity of phytoplankton sampled on day 101 was $7 \times 10^{-6} \mathrm{~ms}^{-1}$ at the surface, and $7.5 \times 10^{-6} \mathrm{~m} \mathrm{~s}^{-1}$ at $3 \mathrm{~m}$ above the bottom.

\subsection{Spatial surveys}

Results of the spatial SEAROVER surveys are presented in Figs. 4-15. The figures should be read as follows: the survey started on day $96,13: 55 \mathrm{~h}$ at NW10 with the ship steaming in offshore direction (Fig. 6a). At 15:09 h NW25 (25 km offshore on the Noordwijk transect) was reached and the ship turned. At 15:23 h the turn was completed and the ship steamed in on-shore direction (Fig. 4b), turning at NW5 (5 km offshore on the Noordwijk transect) at 17:05 h. The next lap in offshore direction (from NW5 to NW25) lasted from 17:21 h till 19:14, etc.

The density in the Dutch coastal zone is predominantly determined by salinity and hardly influenced by temperature (De Ruijter et al., 1992). Therefore salinity contours are presented instead of density contours.

\subsubsection{Low TKE period}

The low TKE period is illustrated in Figs. 4-9. Fig. 4 represents the salinity distribution on days 96-97, covering a total period of $20 \mathrm{~h}$. At the beginning of the observations at 13:55 on day 96, the water column remained homogeneous for several hours (Fig. 4a and b). At about 17:00, the water 


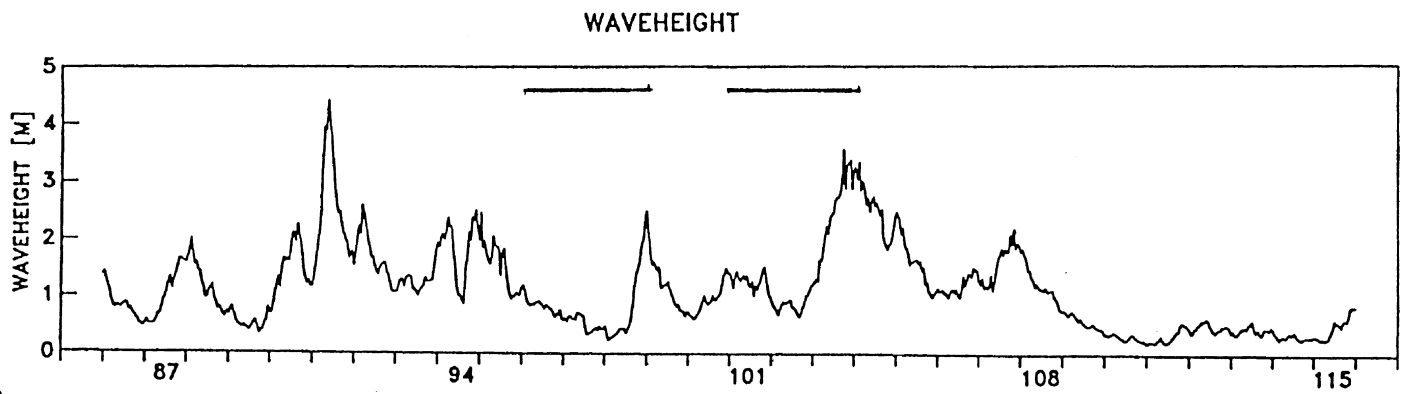

(a)

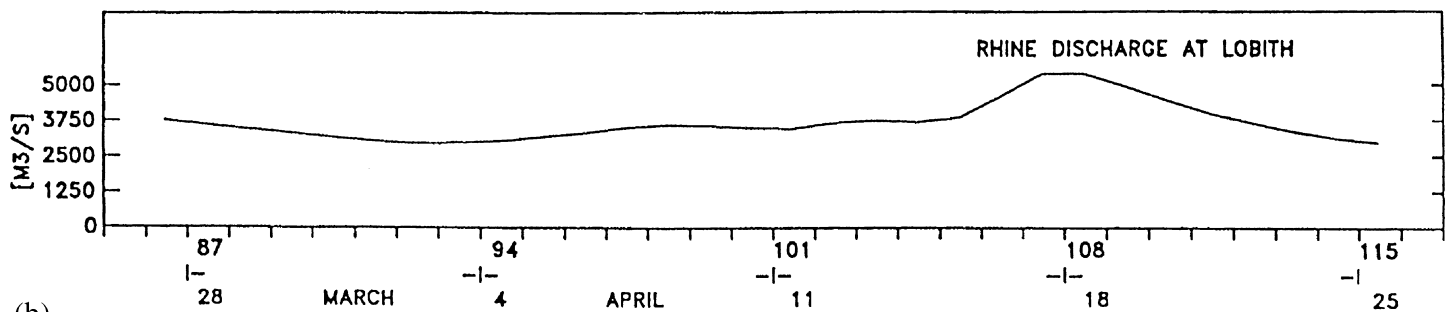

(b)

$$
\text { IRRADIANCE - NW10 }
$$

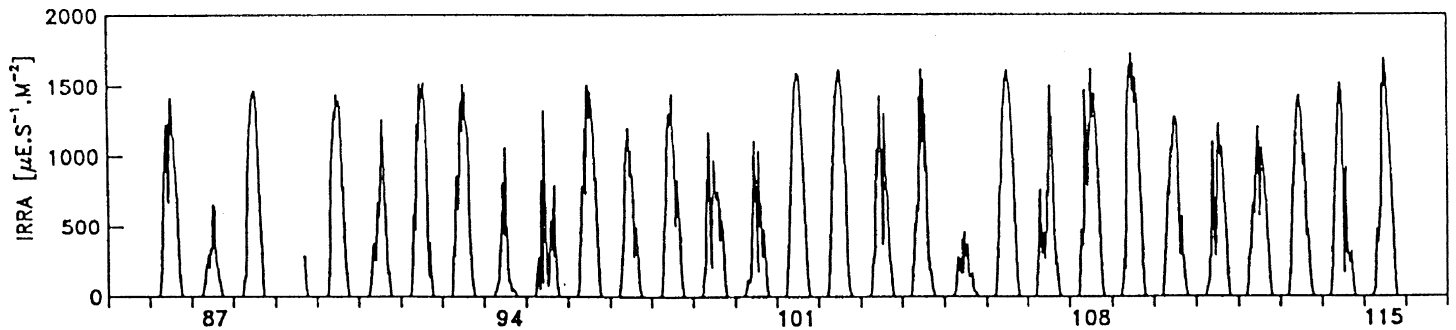

(c)

IRRADIANCE - NW20

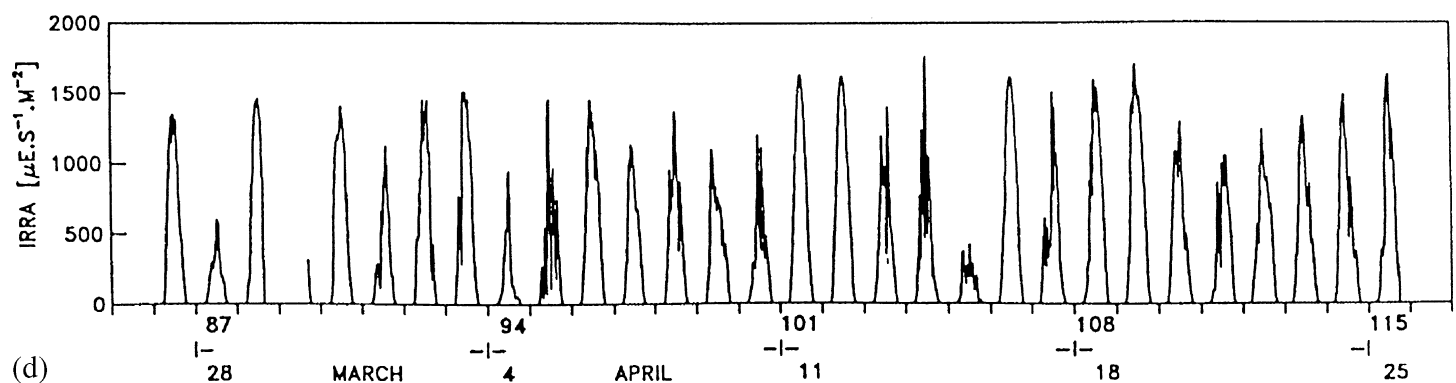

Fig. 2. Time series of (a) wave height (m), the horizontal solid lines on top of the time series indicate the periods when the SEAROVER surveys were carried out; (b) Rhine discharge $\left(\mathrm{m}^{3} \mathrm{~s}^{-1}\right)$; (c) surface PAR at $\mathrm{NW} 10\left(\mu \mathrm{Es}{ }^{-1} \mathrm{~m}^{-2}\right)$; and (d) surface PAR at NW20 $\left(\mu \mathrm{Es}^{-1} \mathrm{~m}^{-2}\right)$. 

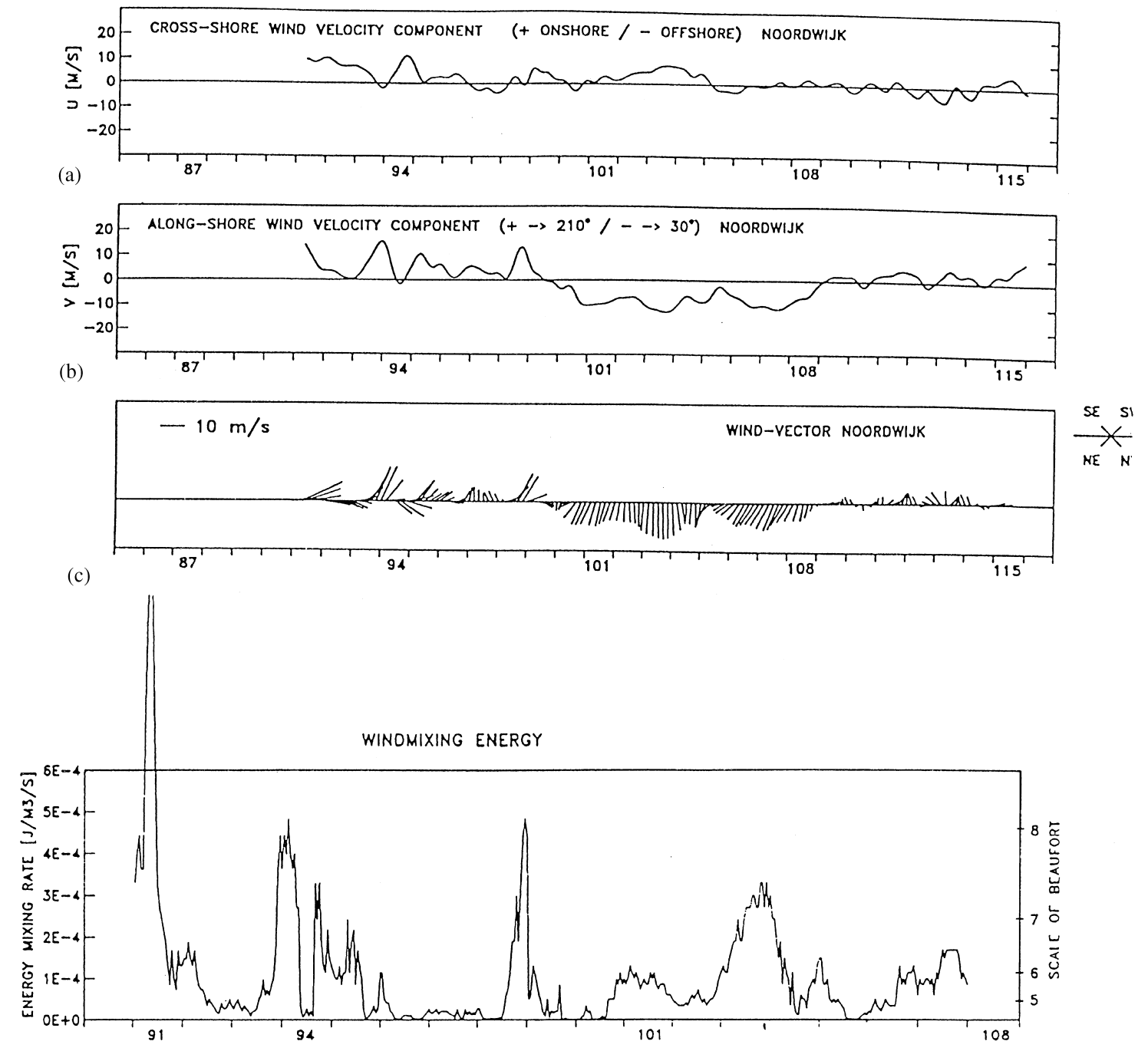

(d)

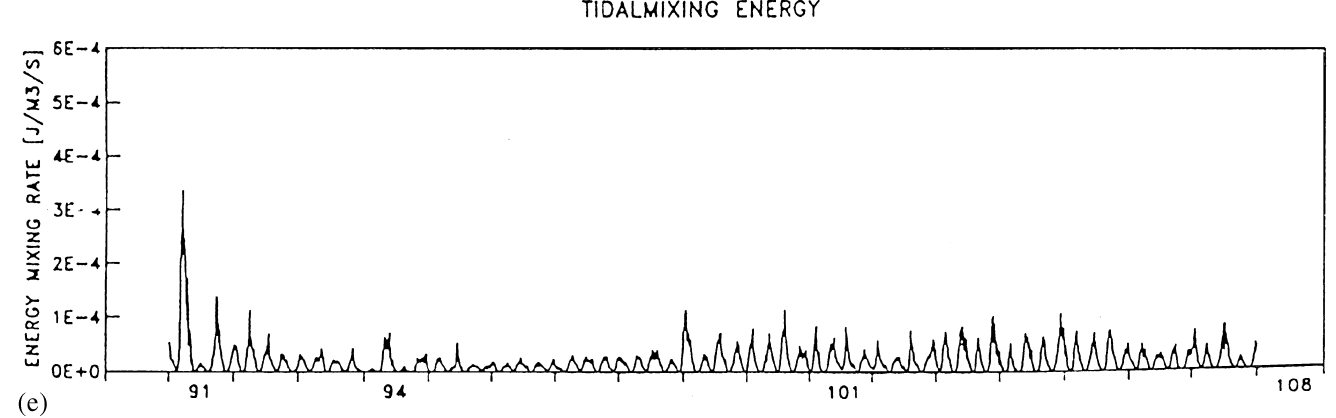

Fig. 3. Time series (a) Cross-shore wind velocity component $\left(\mathrm{m} \mathrm{s}^{-1}\right)$, (b) along-shore wind velocity component $\left(\mathrm{m} \mathrm{s}^{-1}\right)$, (c) wind vector $\left(\mathrm{m} \mathrm{s}^{-1}\right)$, (d) wind mixing energy $\left(\mathrm{W} \mathrm{m}^{-3}\right)$, and (e) tidal mixing energy $\left(\mathrm{W} \mathrm{m}^{-3}\right)$. 


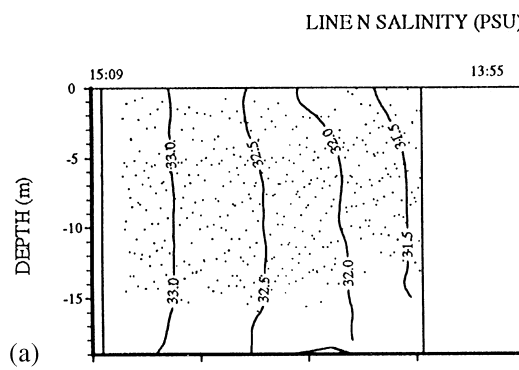

(b)
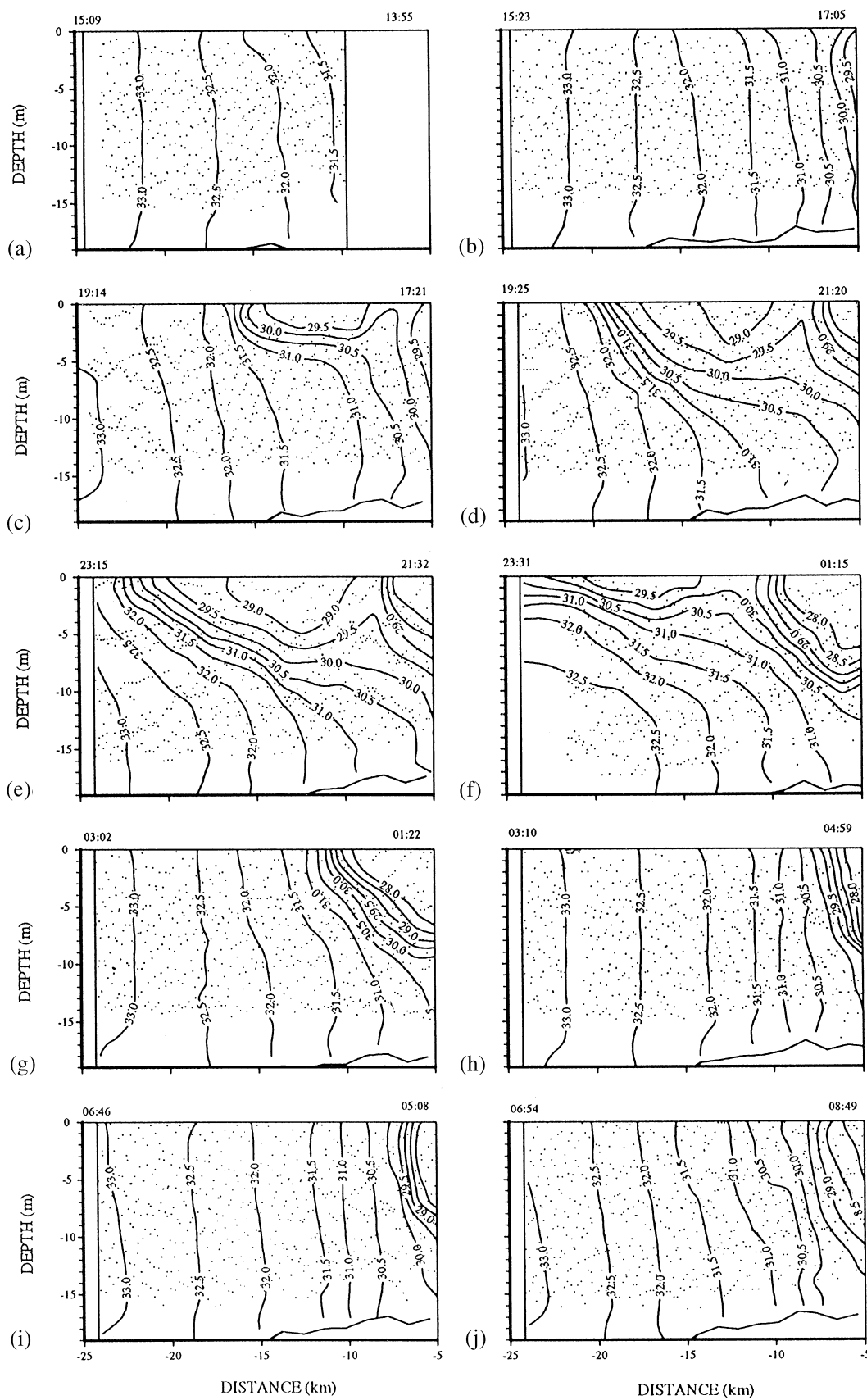

(h)

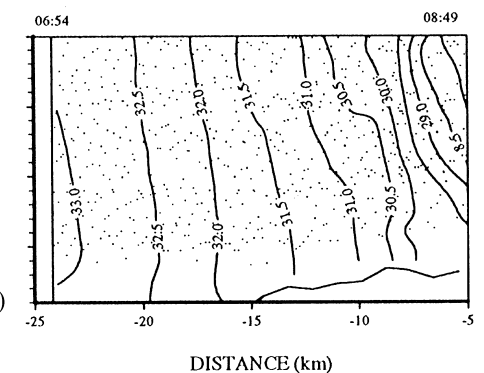

Fig. 4. (a-j) Salinity (psu) distribution on day 96-97, 1994. Time (GMT) is indicated on the upper $x$-axis, distance from shore $(\mathrm{km})$ is given on the lower $x$-axis and depth on the $y$-axis. Contour lines connect points of equal salinity, chlorophyll-a and beam attenuation, respectively. Each dot in between the contour lines represents 10 data points. Refer to text for more details. 


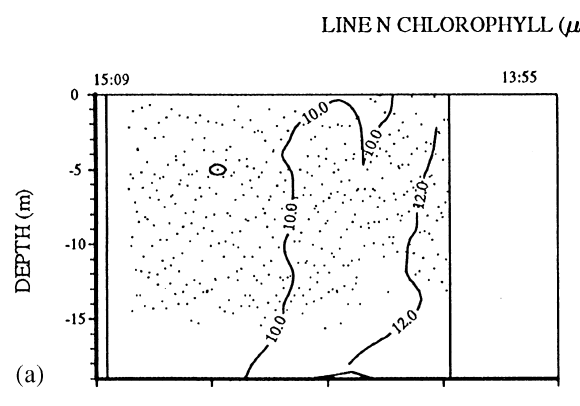

(b)
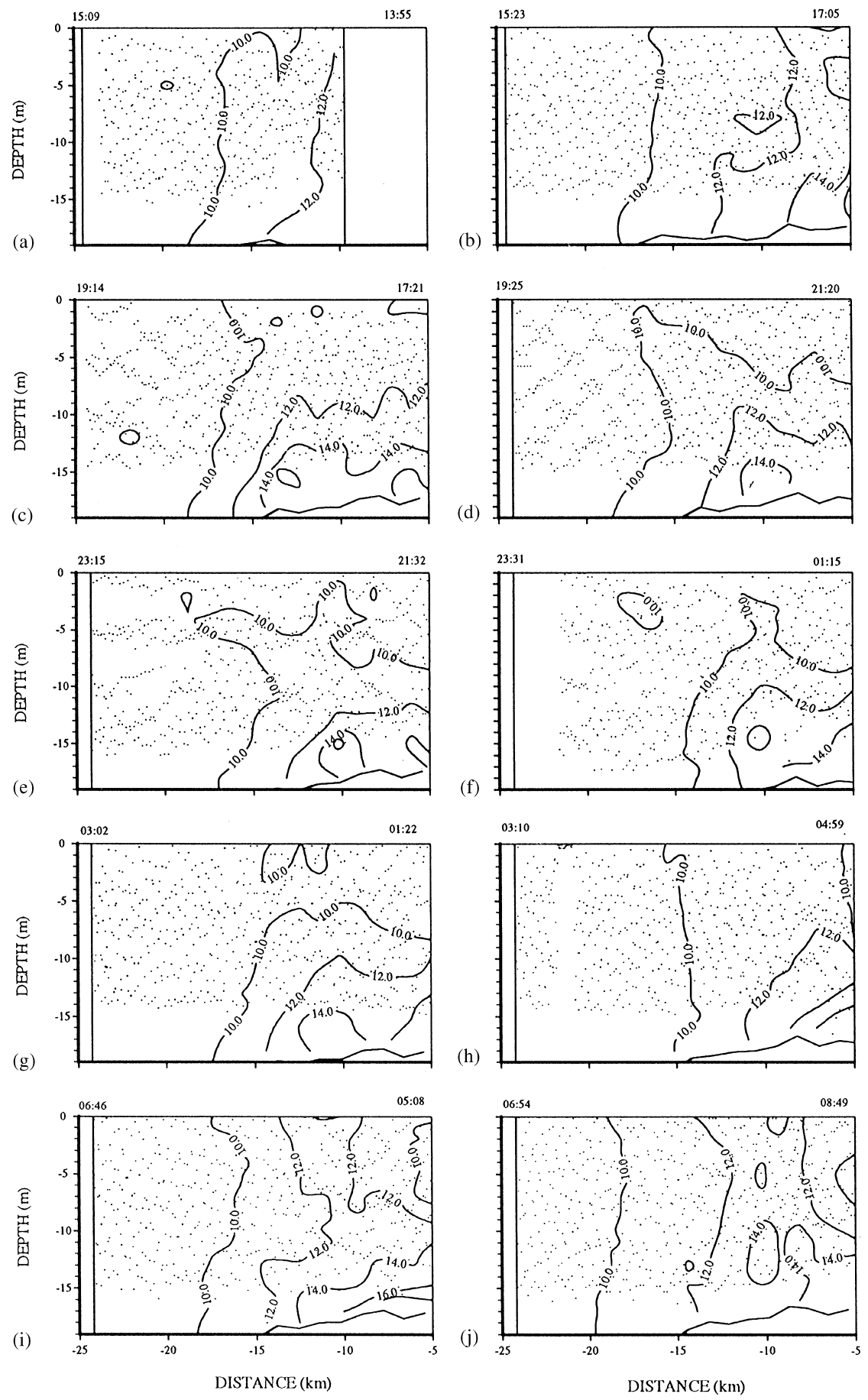

Fig. 5. (a-j) Chlorophyll-a ( $\left.\mu \mathrm{gl}^{-1}\right)$ distribution on day 96-97 1994. See Fig. 4a for details. 
Table 1

Phytoplankton species composition and cell counts (cells per litre)

\begin{tabular}{|c|c|c|c|c|c|}
\hline Phytoplankton species & $\begin{array}{l}101 \\
0 \mathrm{~m}\end{array}$ & $\begin{array}{l}101 \\
15 \mathrm{~m}\end{array}$ & $\begin{array}{l}102 \\
0 \mathrm{~m}\end{array}$ & $\begin{array}{l}102 \\
15 \mathrm{~m}\end{array}$ & $\begin{array}{l}105 \\
0 \mathrm{~m}\end{array}$ \\
\hline Rhizosolenia delicatula & 1297 & 960 & 1160 & 1409 & 1570 \\
\hline Lauderia borealis & 24 & 7 & 15 & 27 & 10 \\
\hline Rhizosolenia shrubsolei & 18 & 21 & 13 & 15 & 27 \\
\hline Rhizosolenia stolterfothii & 16 & 11 & 9 & 27 & \\
\hline Chaetoceros cf. radicans & 12 & & & & \\
\hline Eucampia zodiacus & 12 & 16 & 31 & 20 & 43 \\
\hline Guinardia flaccida & & & & 7 & 9 \\
\hline Chaetoceros compressus & & 5 & & 13 & \\
\hline Leptocylindricus minimum & & & 8 & & \\
\hline Thallasiosira decipiens & & & 8 & 5 & 30 \\
\hline Plagiogramma brockmanni & & & & 5 & 15 \\
\hline Asterionella glacialis & & & & 6 & 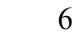 \\
\hline Melosira sulcata & & & & 5 & \\
\hline Cerataulina bergonii & & & & & 10 \\
\hline Thalassionema nitzschioides & & & & & 18 \\
\hline
\end{tabular}

column started to stratify (Fig. 4c), with stratification lasting till about 01:00 on day 97 (Fig. 4d-f). Then stratification disappeared (Fig. 4g) and the water was again homogeneous (Fig. $4 \mathrm{~h}-\mathrm{j}$ ). Simultaneous measurements of chlorophyll-a gave values in the order of $12 \mu \mathrm{gl} \mathrm{l}^{-1}$ with maximum values of around $14 \mu \mathrm{gl} 1^{-1}$ near the bottom at NW10 (Fig. 5). Lowest values were observed offshore from NW15 and in the nearshore surface water. The beam attenuation (Fig. 6) exhibited similar behaviour to that of the chlorophyll-a concentration, with maximum values at a depth of $10-15 \mathrm{~m}$ at NW10, and lowest offshore from NW15. A similar pattern for salinity, chlorophyll-a and beam attenuation on days 97-98 is presented in Figs. 7-9.

\subsubsection{High-energy period}

Salinity contours on day 101-102 are presented in Fig. 10. Although stratification is still visible, gradients are less steep than in the previous days (days 96-98). The chlorophyll-a maximum is higher, increasing to $22 \mu \mathrm{gl}^{-1}$ on day 102, and located between NW5 and NW10 (Fig. 11). Beam attenuation is of the same order of magnitude as on day $96-98$, and the maximum is also located between NW5 and NW10 (Fig. 12). In Fig. 15a-h, the water column remained mixed over an entire tidal cycle on days 102-103. Chlorophyll-a values were higher, with maximum values of $26 \mu \mathrm{g} \mathrm{I}^{-1}$ nearshore and at the surface (Fig. 14a-h). The observed beam attenuation was vertically homogeneous with maximum values nearshore, and was similar in magnitude $\left(2-5 \mathrm{~m}^{-1}\right)$ to that found in the low TKE period (Fig. 15a-h). The patches of high chlorophyll-a concentration near the surface (Figs. 11a, 14b and d) were not reflected in the beam attenuation signal. During this last observational day 105 the horizontal salinity gradients intensified: note how the 30.5 and 33.5 isohalines suddenly appeared at each end of the study area (Fig. 13i and j). Chlorophyll-a levels were still high on day 105, with maximum values of $26 \mu \mathrm{g}{ }^{-1}$ nearshore and at the surface (Fig. 14i and $\mathrm{j}$ ). The beam attenuation observations showed vertical homogeneity over this entire period 
LINE N ATTENUATION $\left(\mathrm{m}^{-1}\right)$ JULIAN DAY 96 \& 97

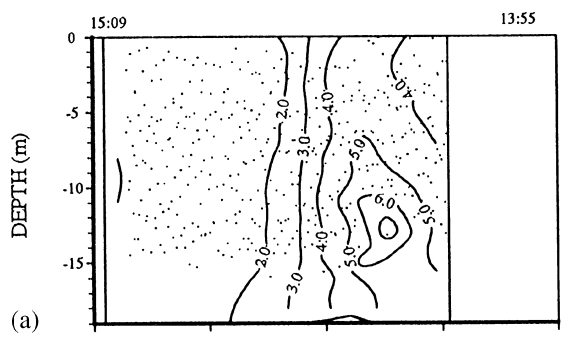

(b)
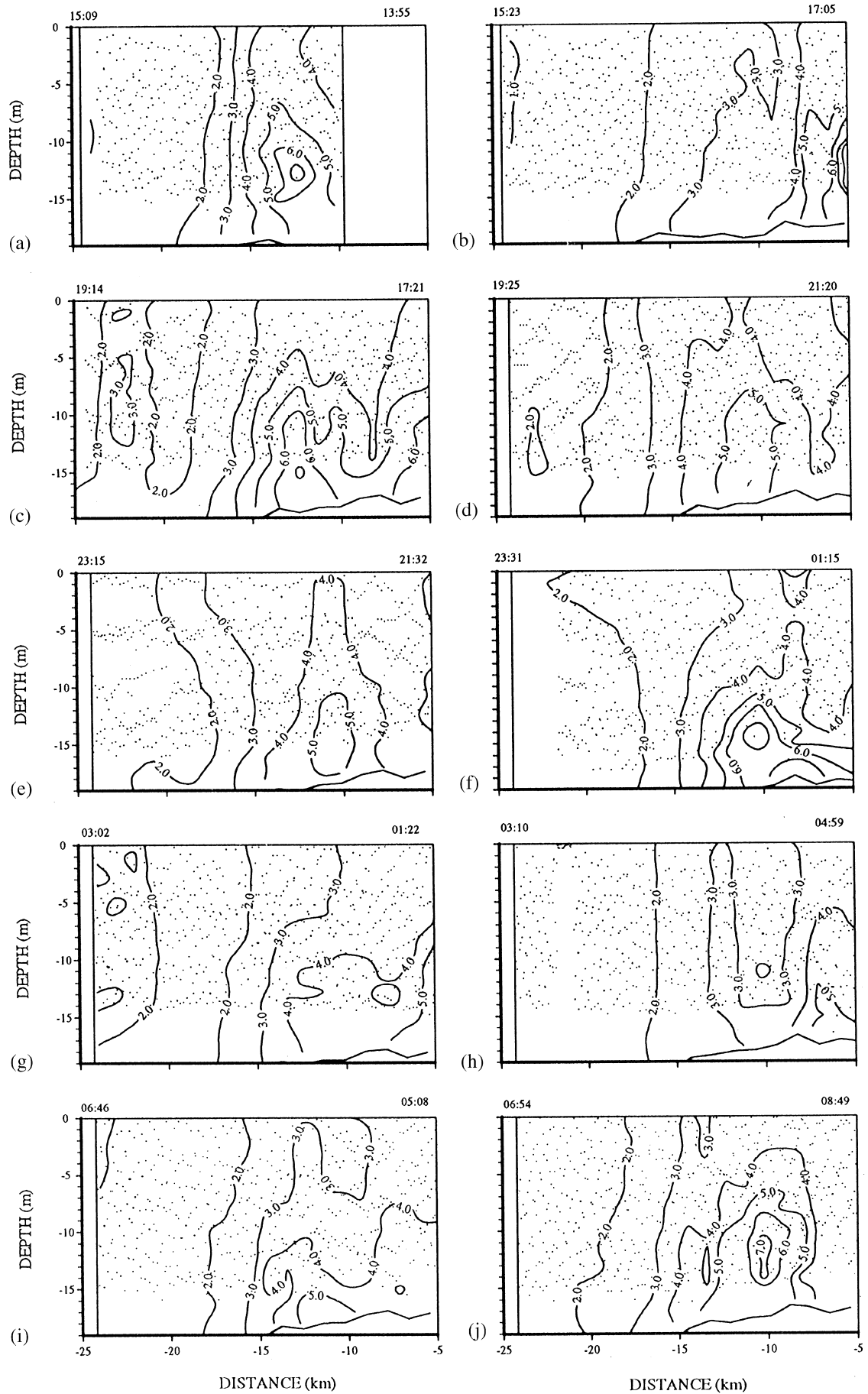

Fig. 6. (a-j) Beam attenuation $\left(\mathrm{m}^{-1}\right)$ distribution on day 96-97 1994. See Fig. 4a for details. 
LINE N SALINITY (PSU) JULIAN DAY 97 \& 98

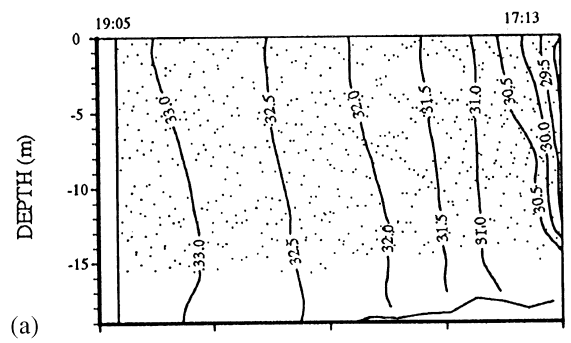

(b)
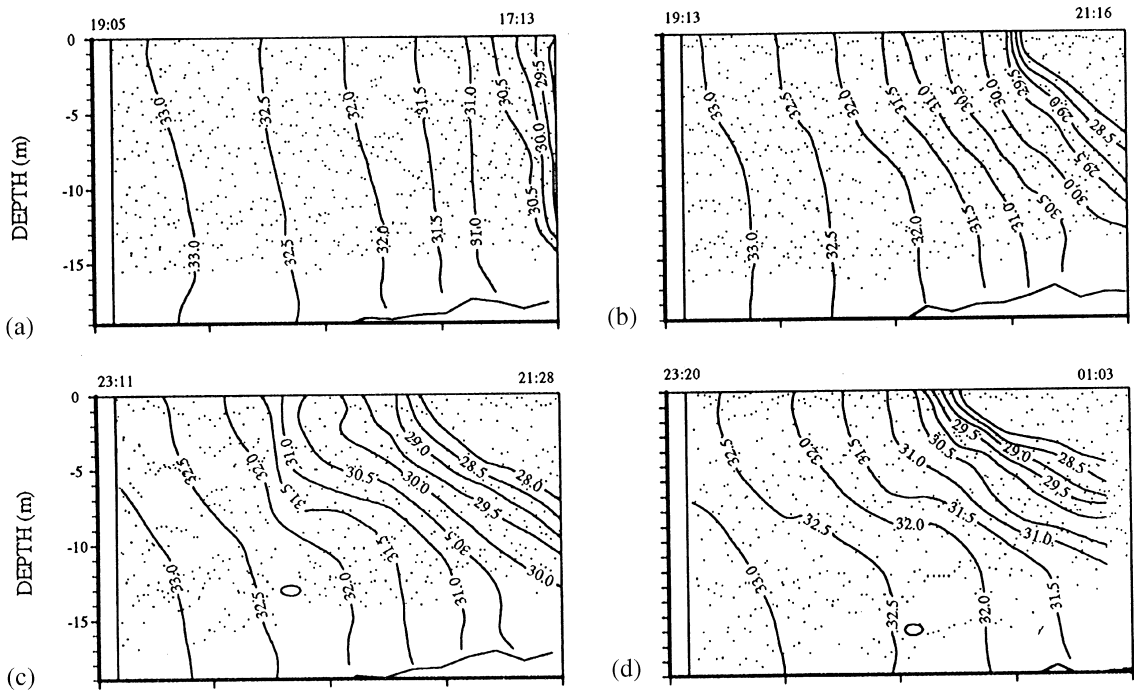

(d)
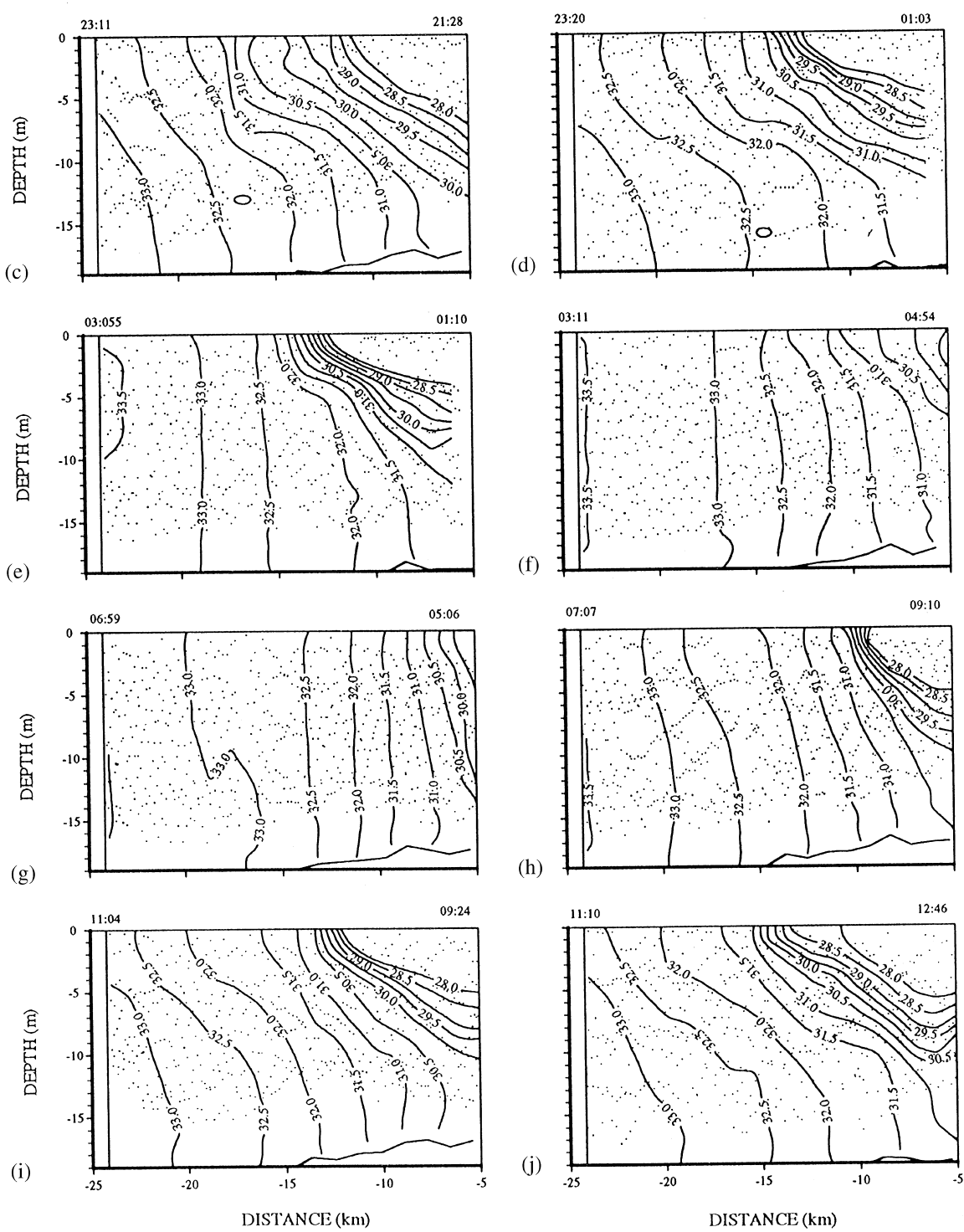

Fig. 7. (a-j) salinity (psu) distribution on day 97-98 1994. See Fig. 4a for details. 
LINE N CHLOROPHYLL $\left(\left.\mu_{g}\right|^{-1}\right)$ JULIAN DAY $97 \& 98$

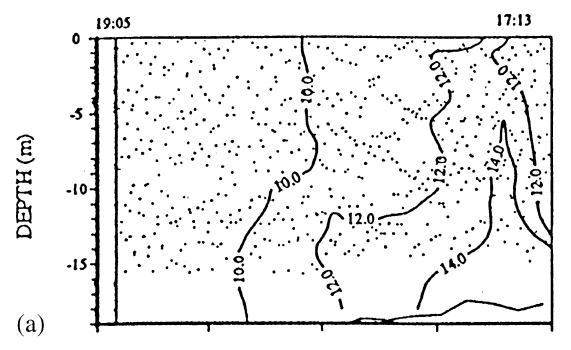

(b)
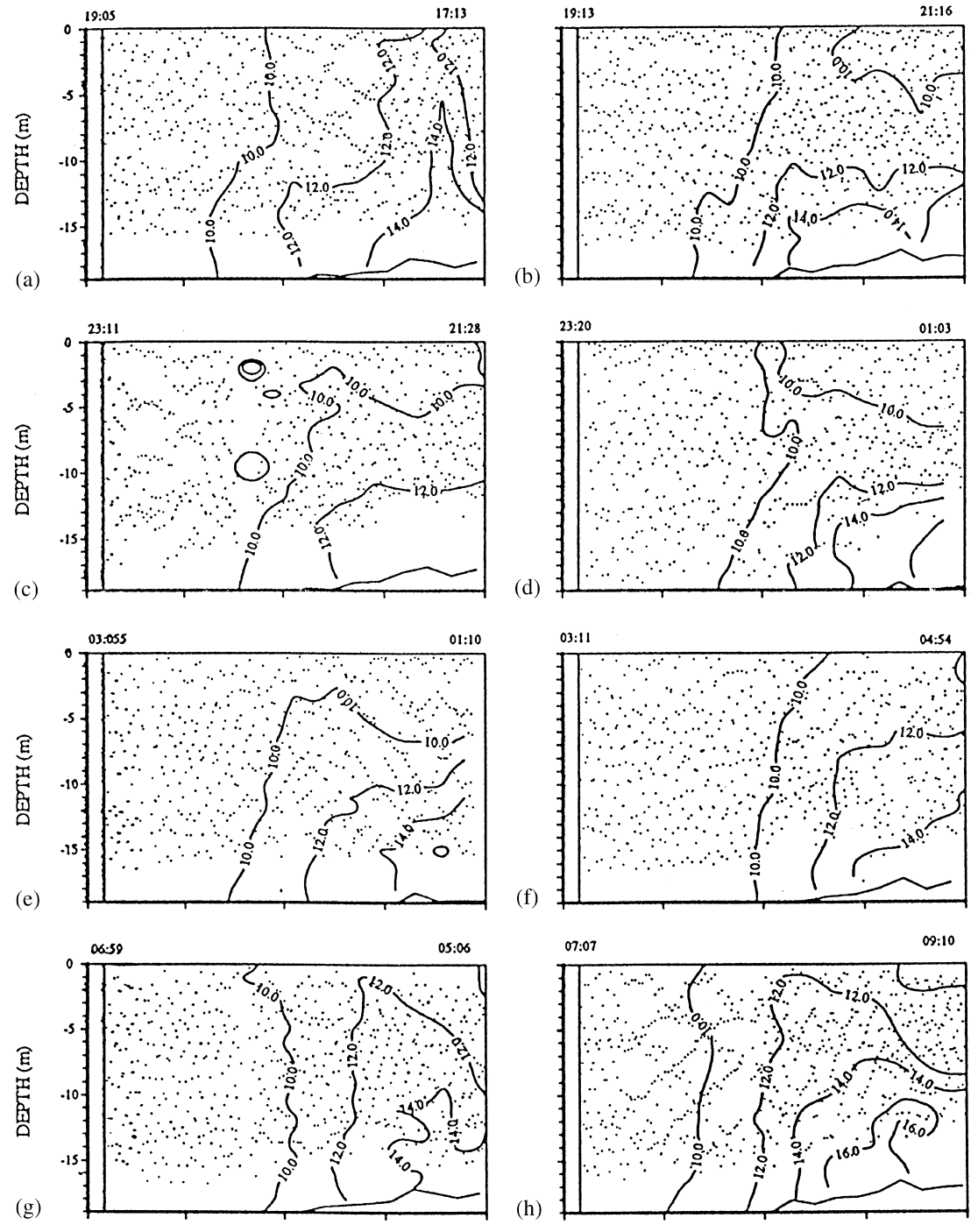

(h)
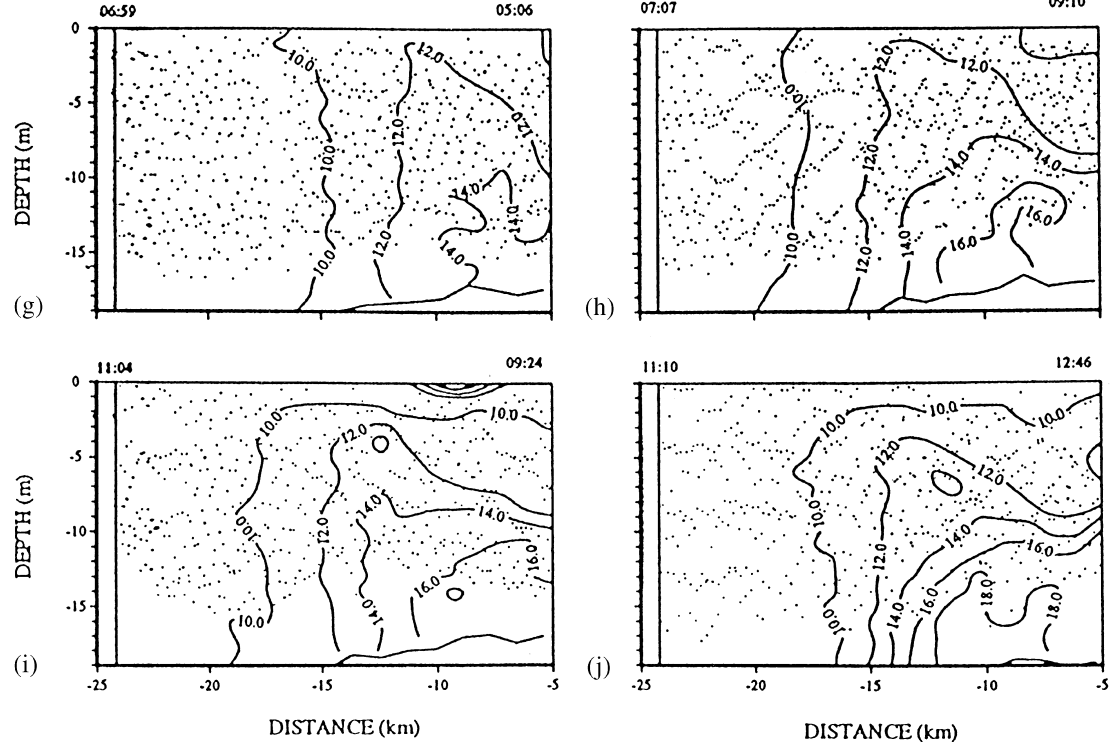

Fig. 8. (a-j) Chlorophyll-a ( $\left.\mu \mathrm{g} 1^{-1}\right)$ distribution on day 97-98 1994. See Fig. 4a for details. 


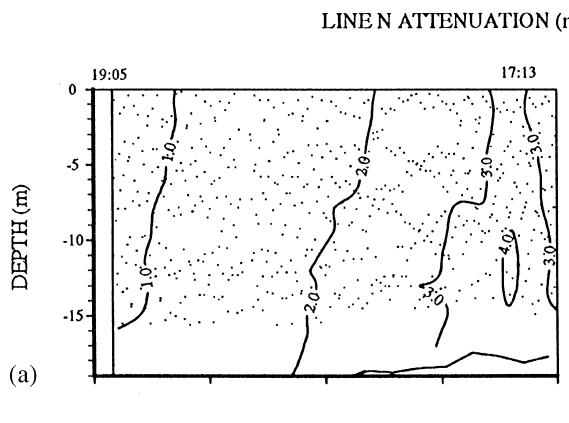

(b)
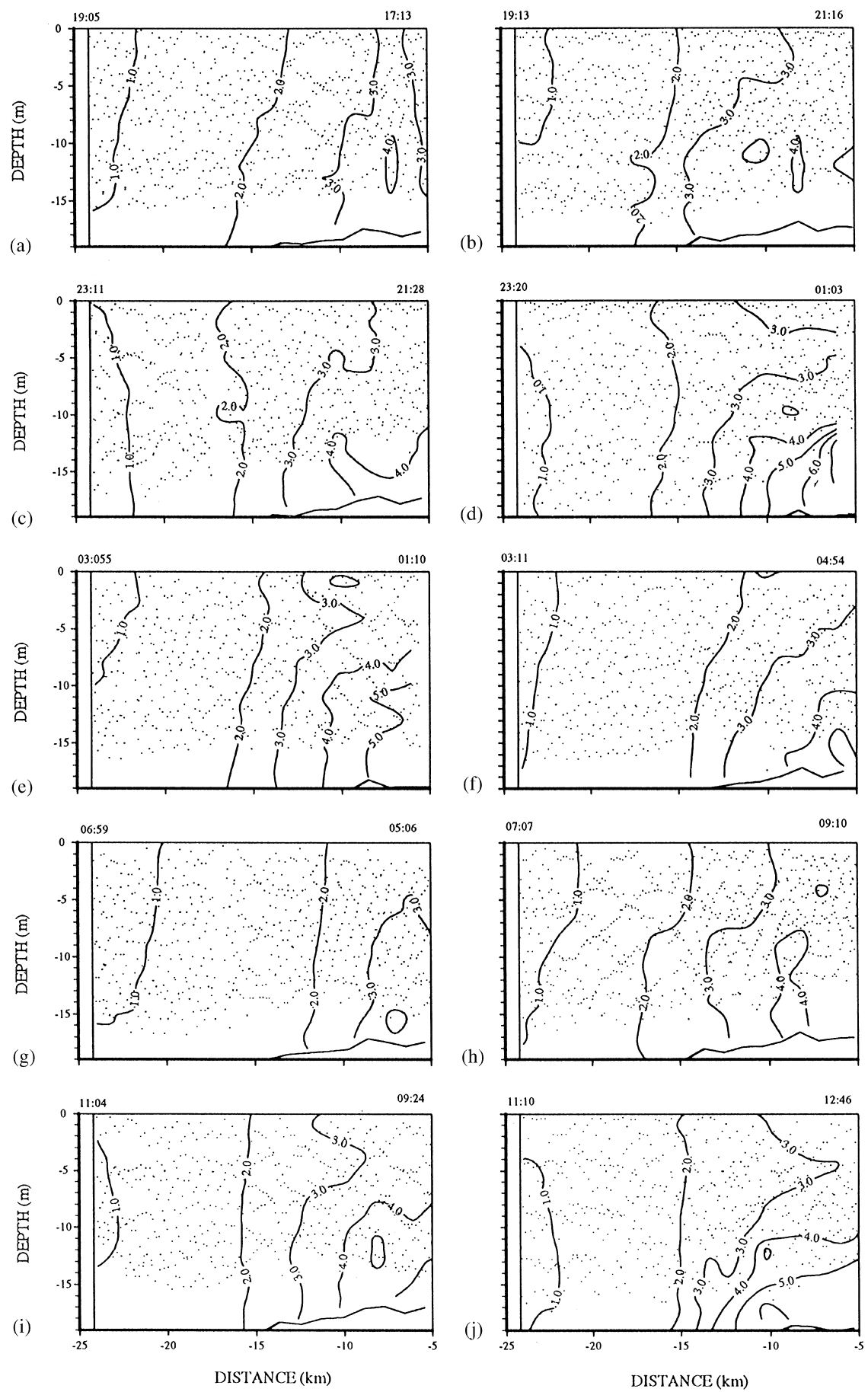

Fig. 9. (a-j) Beam attenuation $\left(\mathrm{m}^{-1}\right)$ distribution on day 97-98 1994. See Fig. 4a for details. 


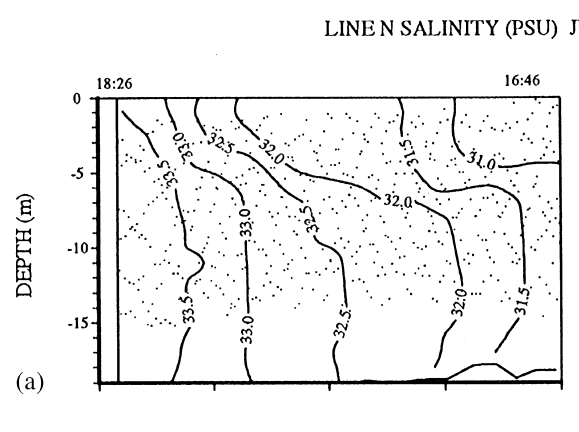

(b)
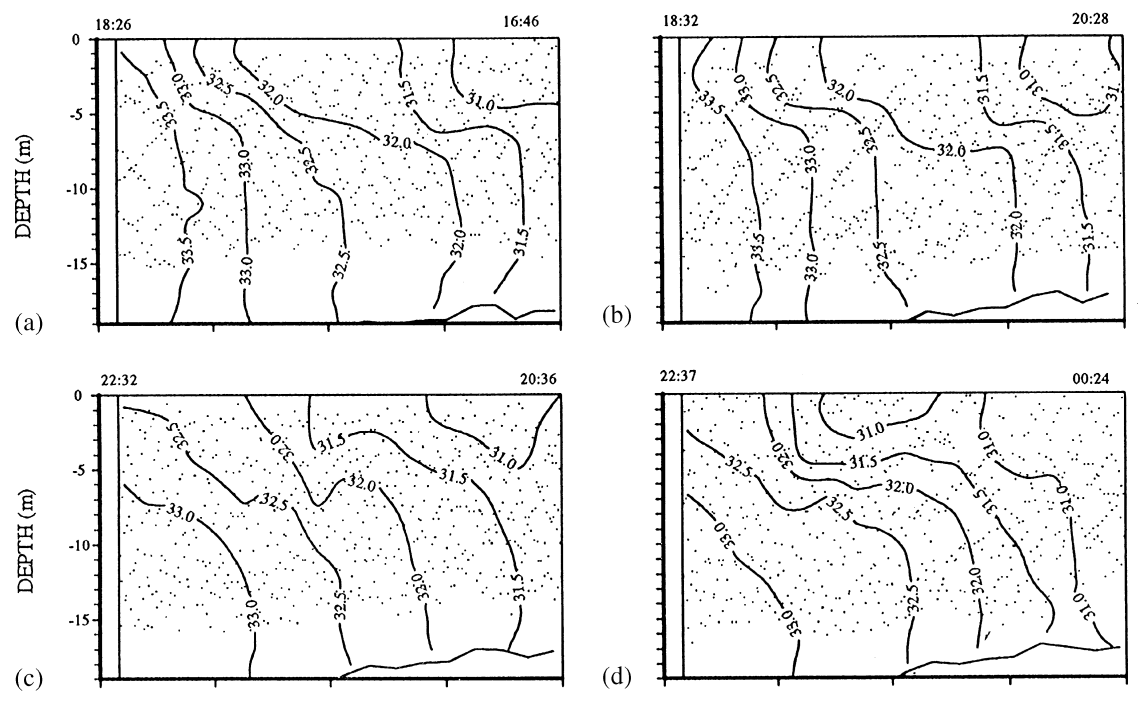

(d)
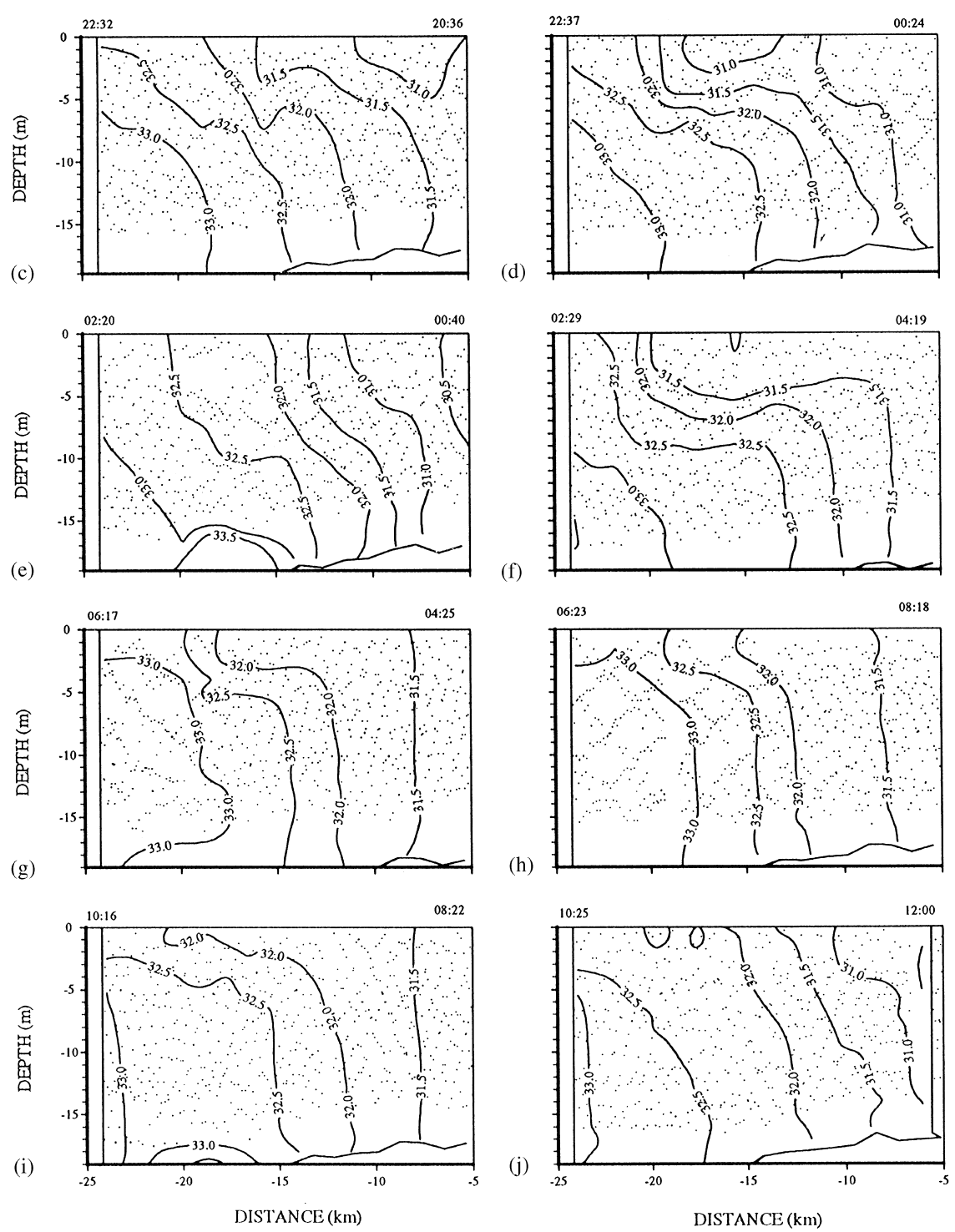

Fig. 10. (a-j) salinity (psu) distribution on day 101-102 1994. See Fig. 4a for details. 
LINE N CHLOROPHYLL $\left(\mu \mathrm{gl} \mathrm{I}^{-1}\right)$ JULIAN DAY $101 \& 102$

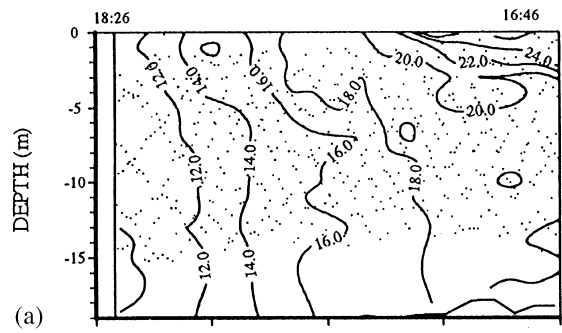

(b)
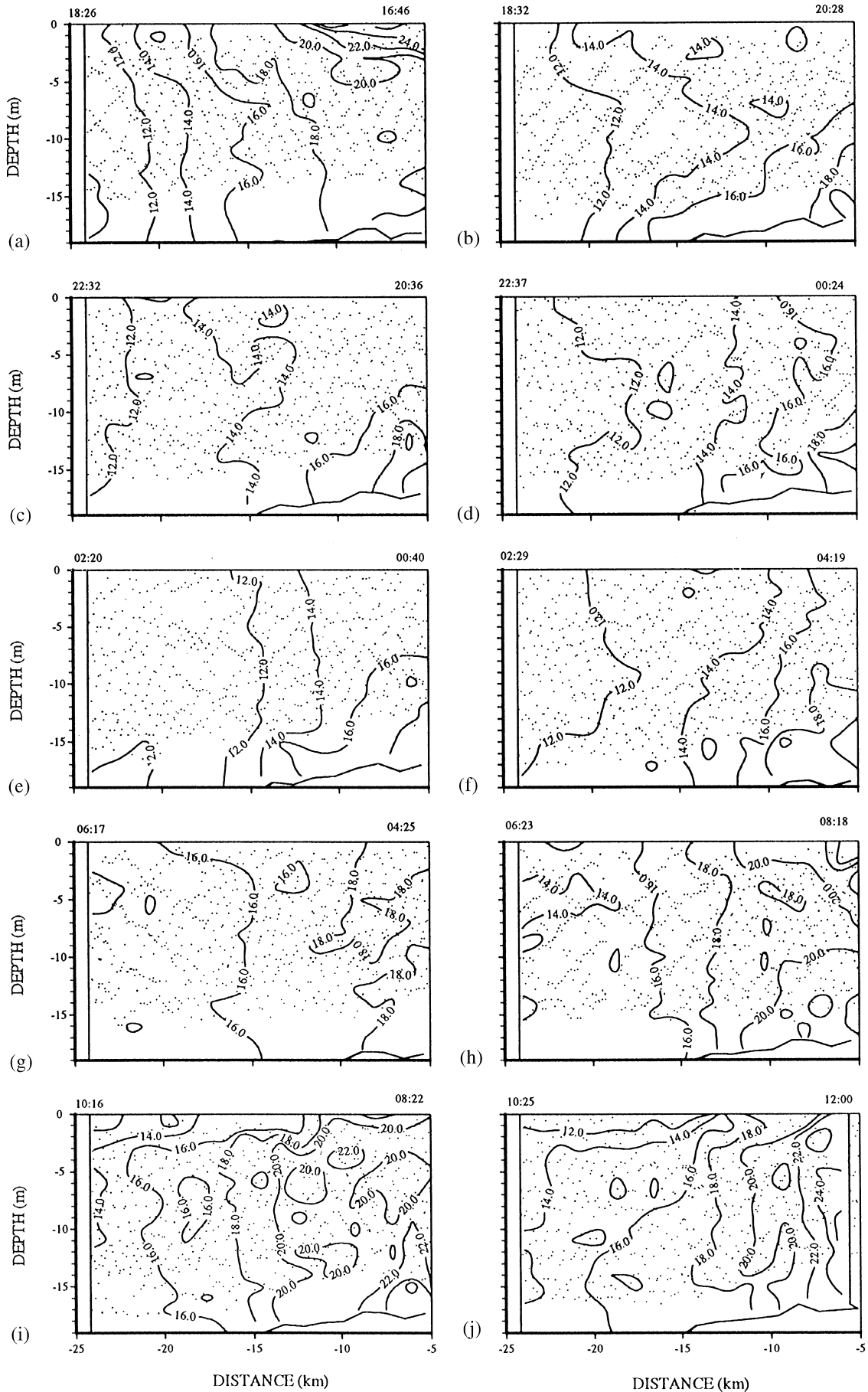

Fig. 11. (a-j) Chlorophyll-a $\left(\mu \mathrm{gl}^{-1}\right)$ distribution on day 101-102 1994. See Fig. 4a for details. 


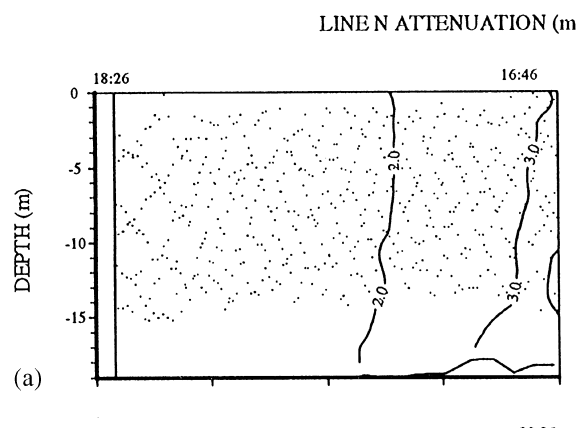

(b)
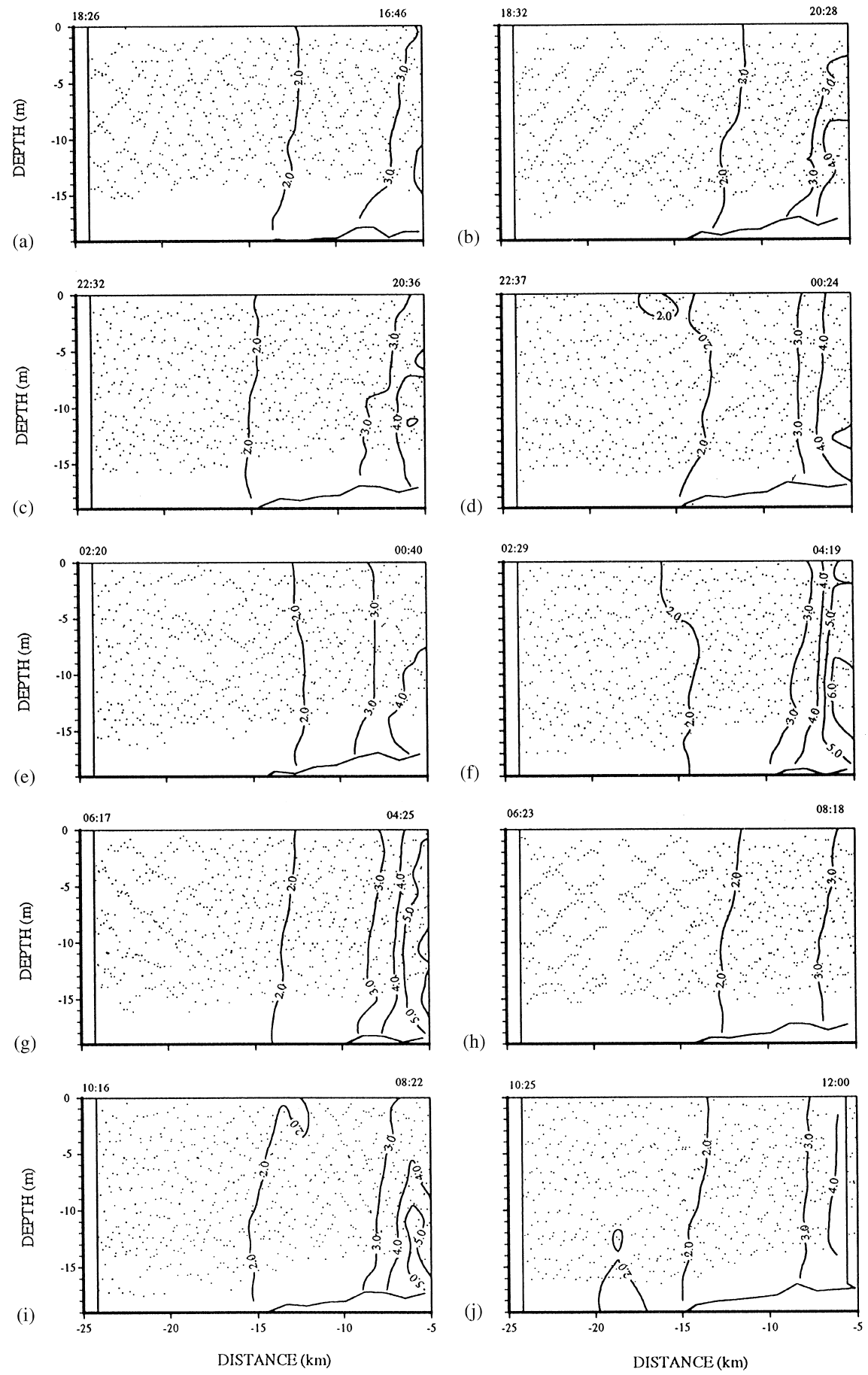

(h)

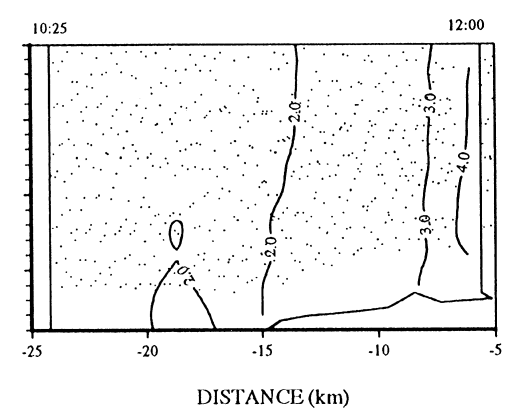

Fig. 12. (a-j) Beam attenuation $\left(\mathrm{m}^{-1}\right)$ distribution on day 101-102 1994. See Fig. 4a for details. 


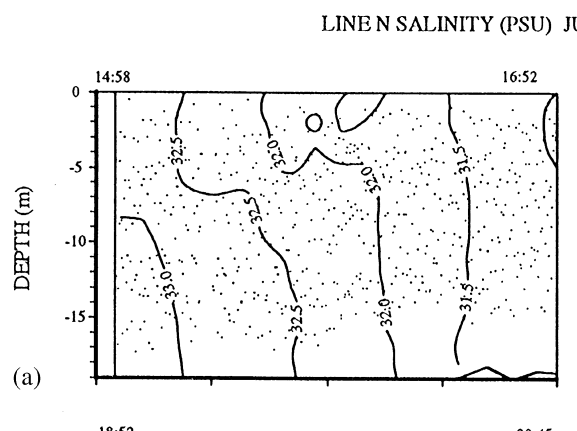

(b)
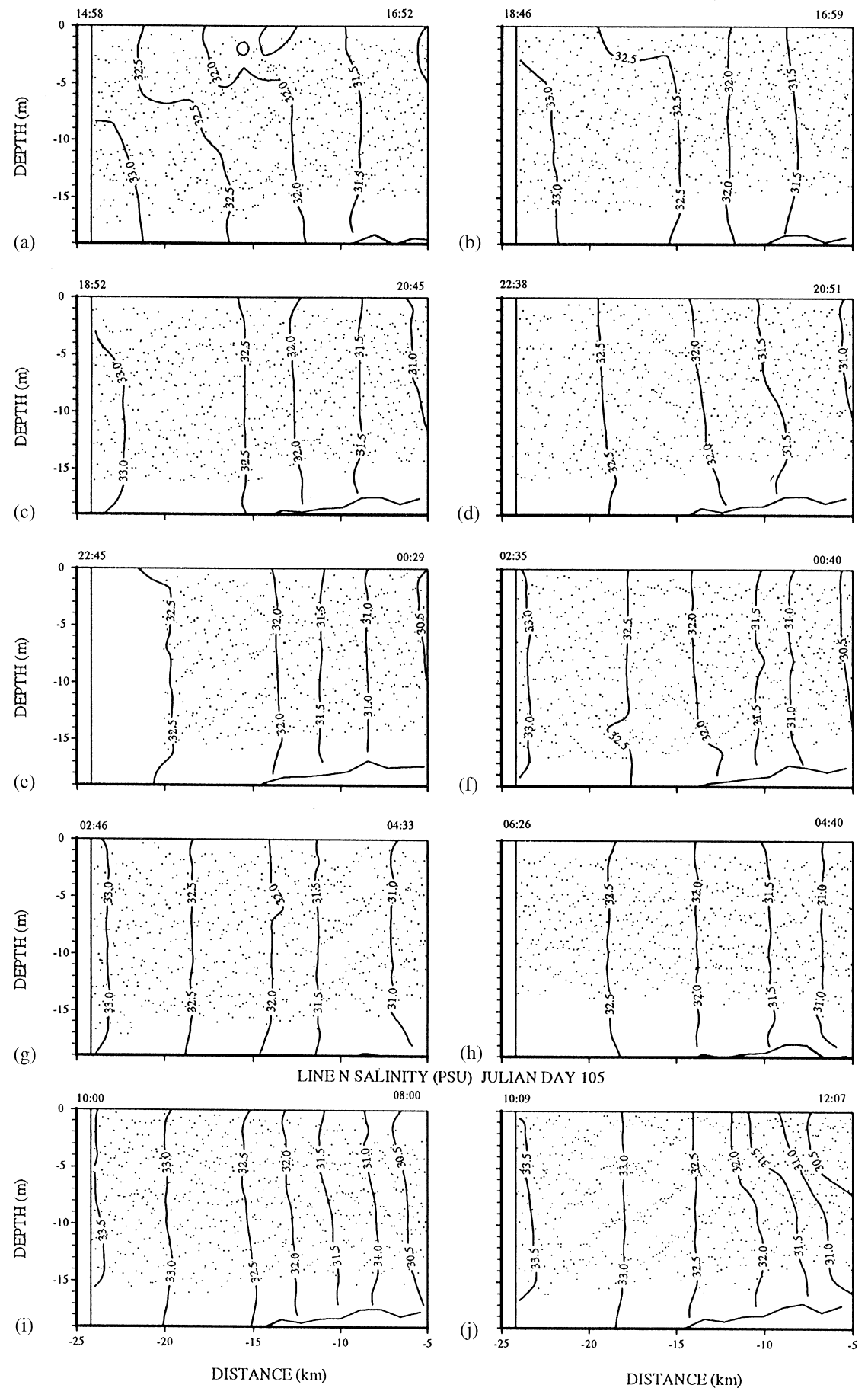

Fig. 13. (a-j) salinity (psu) distribution on day 102-103 and 105 1994. See Fig. 4a for details. 
LINE N CHLOROPHYLL $\left(\mu \mathrm{gl} \mathrm{I}^{-1}\right)$ JULIAN DAY $102 \& 103$

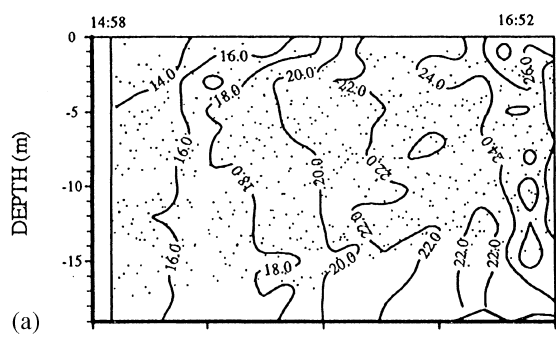

(b)
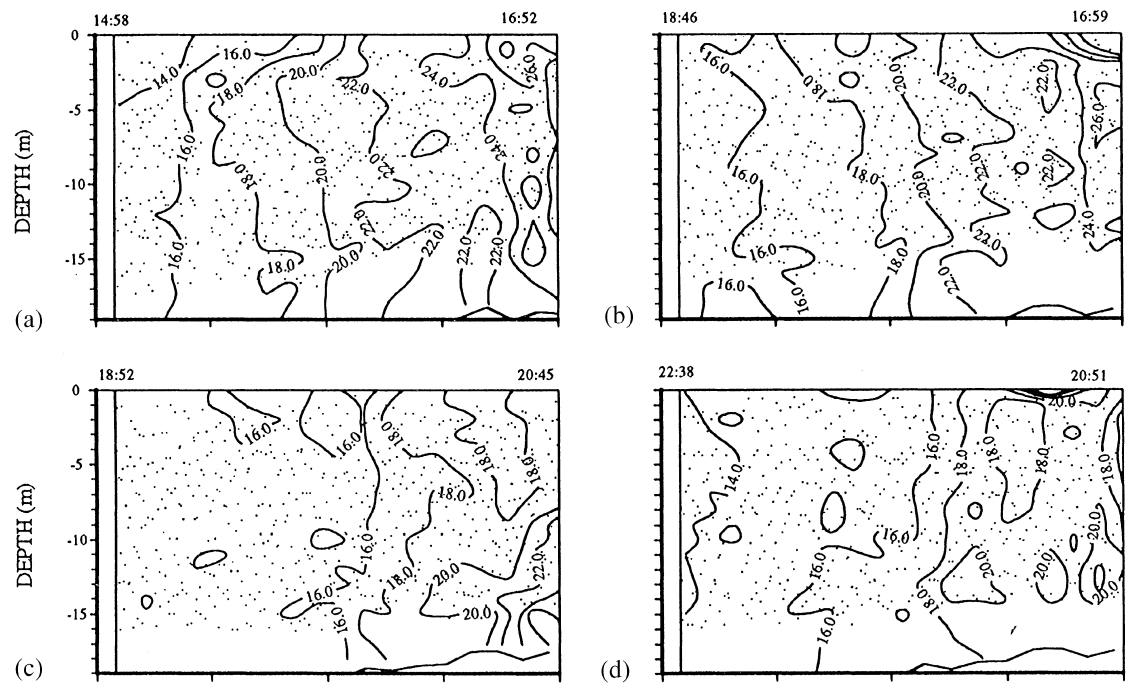

(d)
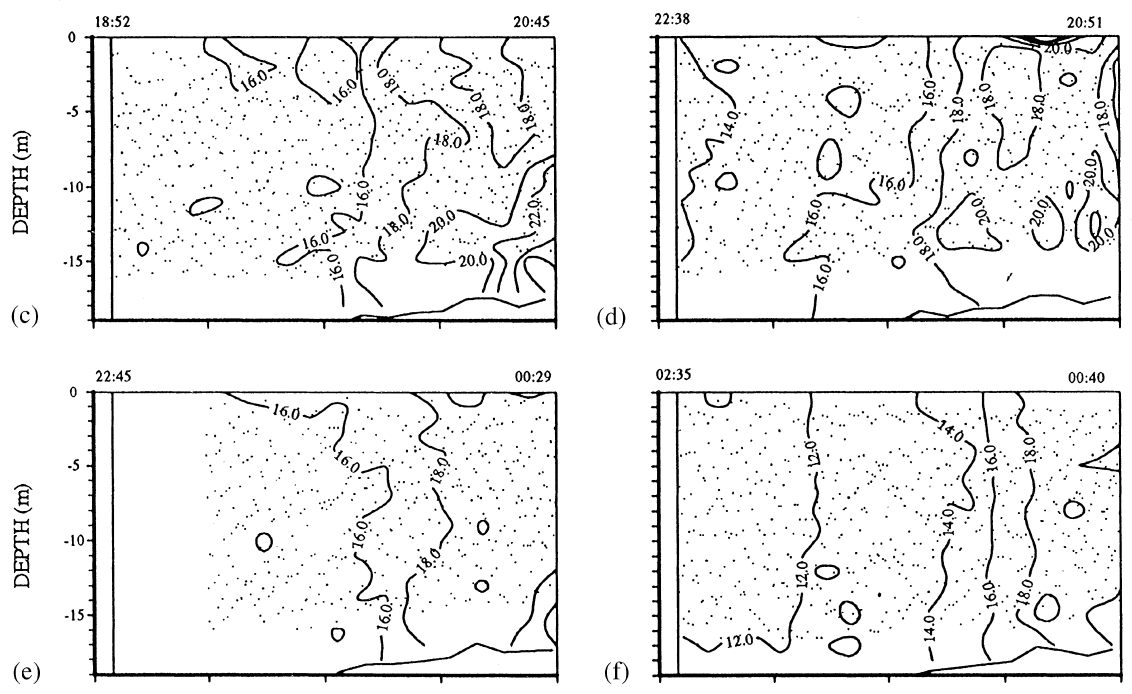

(f)
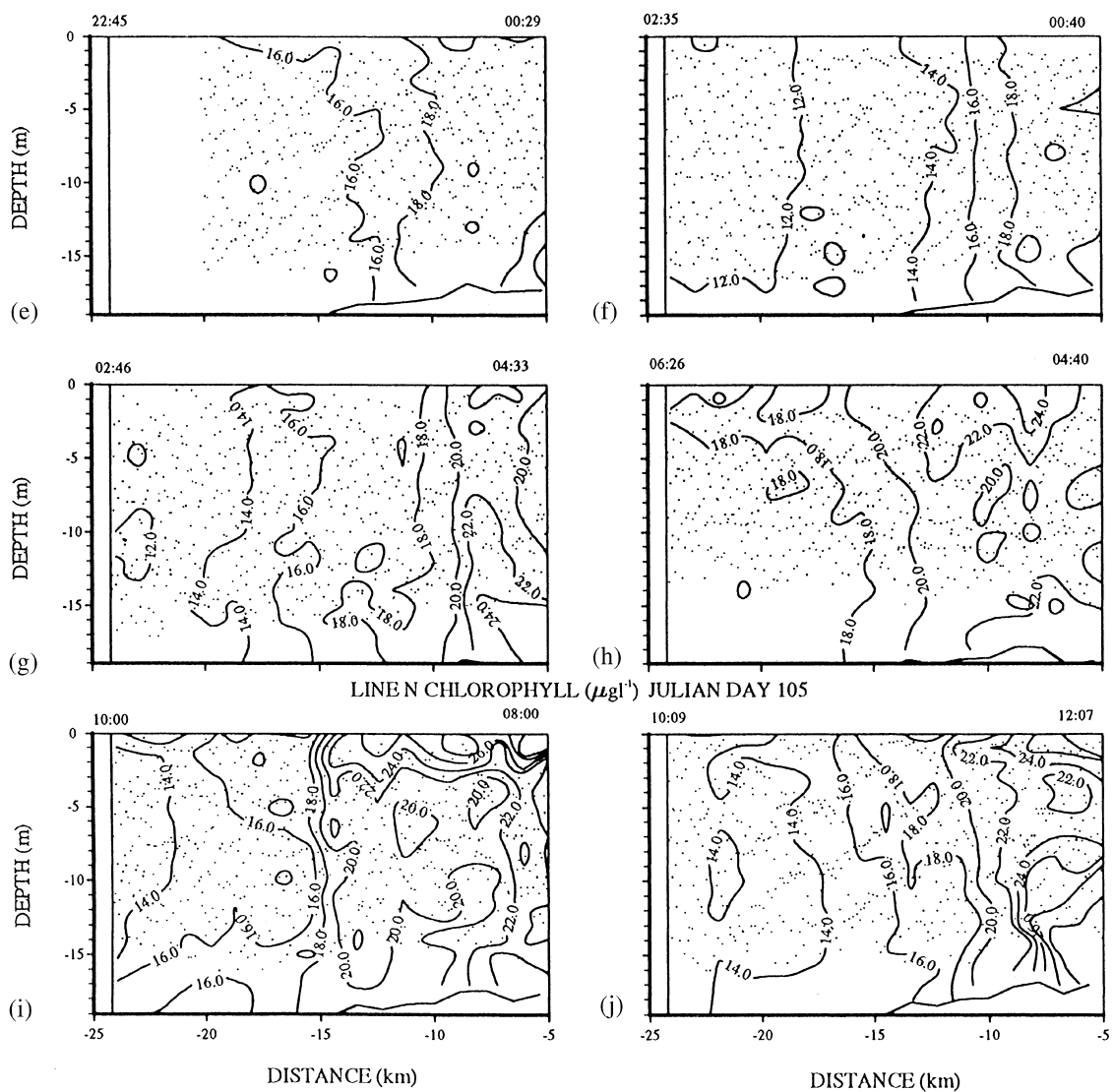

Fig. 14. (a-j) Chlorophyll-a $\left(\mu \mathrm{gl}^{-1}\right)$ distribution on day 102-103 and 105 1994. See Fig. 4a for details. 
LINE N ATTENUATION $\left(\mathrm{m}^{-1}\right)$ JULIAN DAY $102 \& 103$

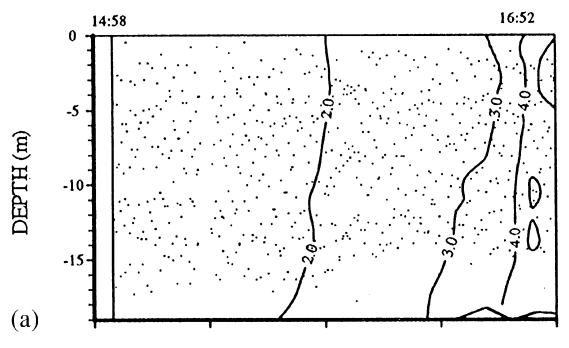

(b)
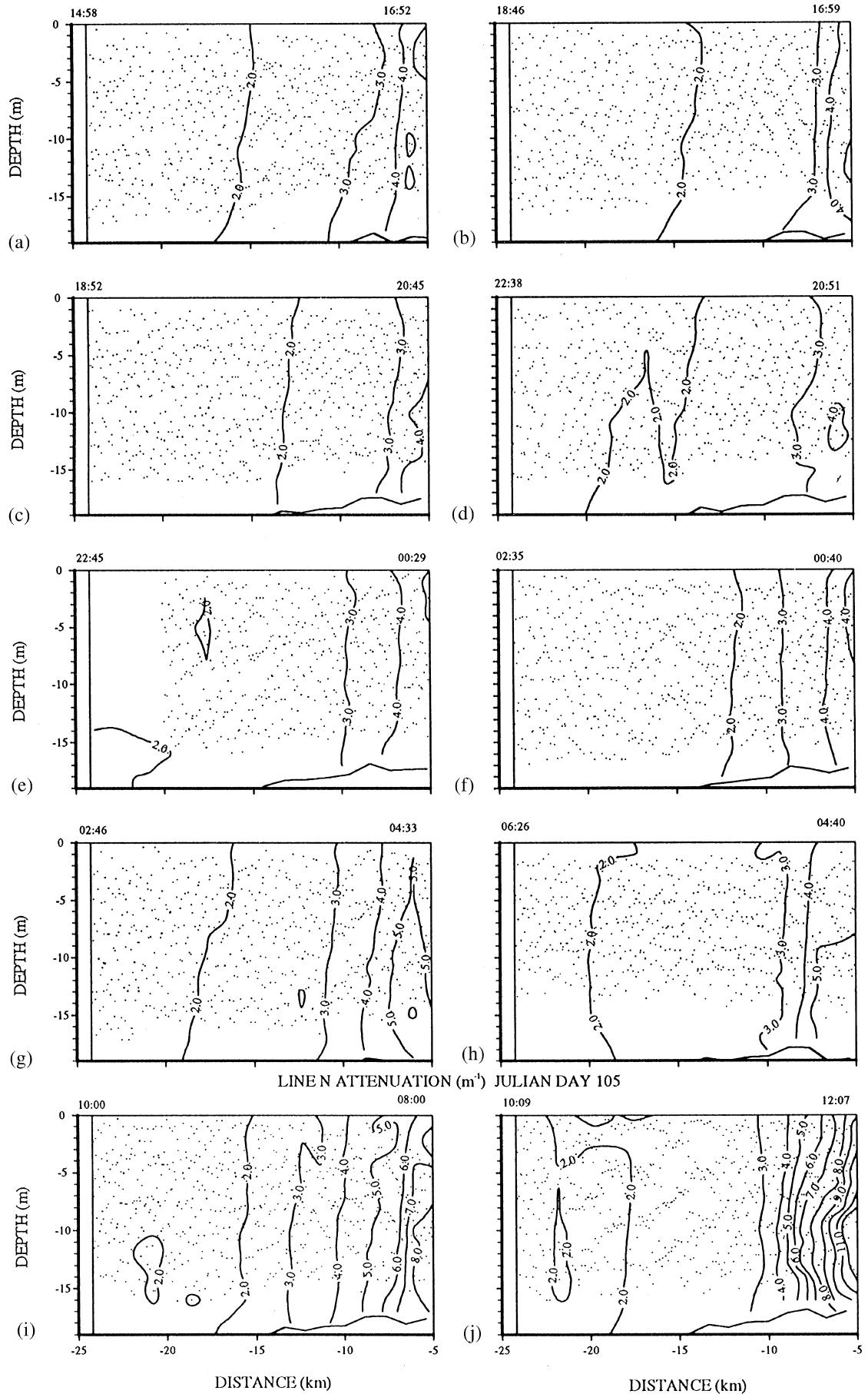

Fig. 15. (a-j) Beam attenuation $\left(\mathrm{m}^{-1}\right)$ distribution on day 102-103 and 105 1994. See Fig. 4a for details. 
with minimum values offshore and higher values nearshore, with horizontal gradients intensified, similar to the salinity distribution (Fig. $15 \mathrm{i}$ and j).

\section{Discussion}

SEAROVER salinity plots during the low TKE period (days 96-98) clearly show a semi-diurnal oscillation in stability, with a frontal zone between 10 and $15 \mathrm{~km}$ offshore. During the stratified period of the tidal cycle, relatively fresh plume water, with low phytoplankton concentration, spread over water with relatively higher salinity and phytoplankton concentration: plume water extended till $15-20 \mathrm{~km}$ offshore. In contrast, during the homogeneous period (caused by tidal straining, not by mixing), the plume water did not spread beyond $5 \mathrm{~km}$ offshore.

During the low TKE period, maximum values of chlorophyll-a $\left(12-16 \mu \mathrm{g} 1^{-1}\right)$ and beam attenuation (4-6 m $\left.{ }^{-1}\right)$ were observed constantly around $10 \mathrm{~km}$ offshore, at a depth of $10-15 \mathrm{~m}$. A physical explanation for this phenomenon may be found in the results obtained by Visser (1993), who applied a three-dimensional circulation model to the Dutch coastal zone to study the advective transport of suspended matter due to wind- and density-driven circulation. Visser demonstrated that particles, with a settling velocity comparable to the vertical circulation components, could be held in suspension in a region of retention near the density front. The vertical density driven velocity component, calculated at the Noordwijk transect with a southerly wind of $10 \mathrm{~m} \mathrm{~s}^{-1}$, were upward directed $\left(10^{-5}-5 \times 10^{-5} \mathrm{~m} \mathrm{~s}^{-1}\right)$ shoreward of the density front, while seaward of the front the velocities were downward directed $\left(10^{-5}-6 \times 10^{-5} \mathrm{~m} \mathrm{~s}^{-1}\right)$. The model showed that suspended material, with a settling velocity of $5 \times 10^{-6} \mathrm{~m} \mathrm{~s}^{-1}$, might be retained in an area between 8 and $10 \mathrm{~km}$ offshore, at a depth between 4 and $17 \mathrm{~m}$. This is in agreement with our observations of the chlorophyll-a and beam attenuation maxima in, considering that the measured phytoplankton mean settling rate was about $6 \times 10^{-6} \mathrm{~m} \mathrm{~s}^{-1}$.

During the second week of observations (days 101-105) the high input of TKE, due to the combined effect of wind, waves and tide, gradually broke down the stratification, and on day 105 enhanced the gradients in salinity and beam attenuation by suppressing the "estuarine" transport. Chlorophyll-a concentrations increased to $14-26 \mu \mathrm{g} 1^{-1}$, with maximum values between 5 and $15 \mathrm{~km}$ offshore at the surface and near the bottom. When comparing day 101 to day 105, both chlorophyll concentrations and phytoplankton cell numbers had increased by roughly a factor of 1.5; this supports the assumption that the observed increase in chlorophyll-a concentration actually reflects an increase in phytoplankton biomass. The increase in phytoplankton can be due to a combination of several factors: (1) local phytoplankton growth, (2) horizontal advection and (3) strong mixing of benthic phytoplankton into the water column. Mixing and resuspension of nutrients and phytoplankton over the whole water column, together with bright sunny weather on days 101 and 102 (Fig. 2d and e) created favourable conditions for phytoplankton growth. Although we assume that the nutrients are not a limiting factor, due to the fact that Rhine waters are rich in nutrients (Simpson et al., 1993), to gain a total understanding of the dynamics of primary productivity, it is necessary to consider the nutrient distribution. Nevertheless, stratification break-up will either allow the nutrients to be resuspended from the bottom reaching the surface layer or the phytoplankton will be allowed to reach the riverine surface nutrients; in either case the end product will be the same: enhanced primary productivity. 
When comparing chlorophyll-a and beam attenuation, it is striking that during the low TKE period they were positively correlated: the maxima were found at exactly the same location. During the high TKE period this was different. The high concentration chlorophyll patches at the surface on days 101 and 102 were not visible at all in the beam attenuation. Moreover, the absolute increase in chlorophyll concentrations was not reflected in an absolute increase in beam attenuation. We can assume that as a result of strong vertical mixing sediment was brought in suspension, and that SPM concentrations (expressed in $\mathrm{mgl}^{-1}$ ) were therefore higher than in the low TKE period. However, the beam attenuation in the high TKE period had not increased compared to the low TKE period.

These observations can be explained by several considerations. During the low TKE period, only material with very low settling velocities (order $10^{-6} \mathrm{~m} \mathrm{~s}^{-1}$ ) could be kept in suspension during the whole tidal cycle. This means that the proportion of phytoplankton in the suspended material was probably higher than the proportion of suspended sediment. As a result, the beam attenuation sensor measured mainly phytoplankton and it is therefore not surprising that the chlorophyll-a and beam attenuation signal were strongly correlated. During the high TKE period, sediment with higher settling velocities (order $10^{-3} \mathrm{~m} \mathrm{~s}^{-1}$ ) could be kept in suspension, and the proportion of terrigenous material in the suspended material would therefore be higher than in the previous week i.e. during the low TKE period. In this case, beam attenuation was caused mainly by the large component of terrigenous material and only in part by phytoplankton, so the signal of fluorometer and transmissometer were not correlated. The fact that the beam attenuation in the high TKE period was not greater than in the low TKE period is contrary to expectations: the increased mixing would keep sediment with higher settling velocities in suspension, and result in a higher beam attenuation. However, origin (planktonic or terrigenous), size of the suspended material at different periods and flocculation processes will strongly influence the magnitude of the signals. For interpretation of beam attenuation and fluorimeter signals, detailed calibration data would be needed: apart from filtered water samples also phytoplankton species composition and properties (size, composition) of suspended material.

\section{Conclusions}

During the low TKE period the Rhine outflow system was dominated by tidal straining, in contrast with the high TKE period when it was dominated by mixing through wind waves and tidal stirring. These physical processes were reflected in measurements of chlorophyll-a and beam attenuation. It is proposed that the suspended particulate matter in the low TKE period consisted mainly of phytoplankton and in the high TKE period of both phytoplankton and sediment.

Although limited in observations i.e. one phytoplankton bloom event, the results are tentatively explained by a hypothesis which is summarised schematically in a conceptual $x-z$ diagram (Fig. 16). Starting at a period of high turbulent kinetic energy, the water column is well mixed with horizontal density gradients and circulation of nutrients throughout the water column. As a result phytoplankton grow mainly at the surface where light conditions are favourable (Fig. 16a). The high TKE period is followed by a low TKE period dominated by tidal straining. Phytoplankton cells sink with a settling velocity of the order of $10^{-6} \mathrm{~m} \mathrm{~s}^{-1}$, but due to frontal circulation are kept in suspension in a region of retention approximately $10 \mathrm{~km}$ off shore, at a depth of $10-15 \mathrm{~m}$ 


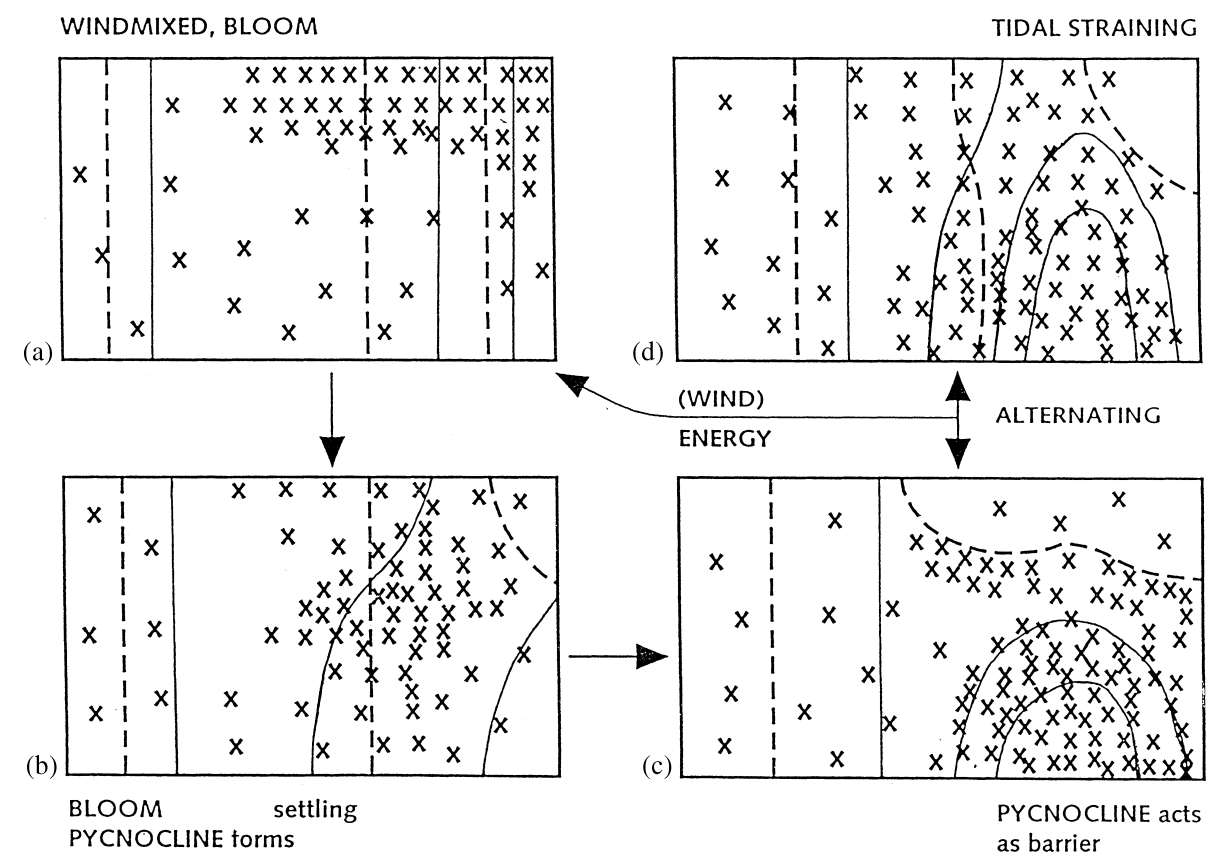

Fig. 16. Conceptual diagram of observations in the Rhine outflow. (- --$)$ represent isohalines, $(-)$ represent isolines of beam attenuation, and $(\times \times \times)$ represent phytoplankton cells.

(Fig. 16b). A pycnocline intermittently overlies the region of retention (Fig. 16c and d). When stratification is established, phytoplankton is limited to a region near but not above the pycnocline (Fig. 16c) and can only reach the surface during the homogeneous part of the tidal cycle (Fig. 16d). The system can switch for several days between situations of well mixed and stratified water, due to tidal straining, as indicated on Fig. $16 \mathrm{c}$ and d, as long as TKE is low and tidal straining is dominant. Phytoplankton can survive because sufficient light penetrates through the clear upper layer and oscillations in stratification ensure that phytoplankton reaches the surface during several hours every tidal cycle. When TKE increases again, e.g. as a result of a new wind event, the system finds itself again in the situation described in Fig. 16a. Provided there is enough light and nutrients, either from bottom resuspension or from riverine origin, a new phytoplankton bloom may occur.

It can be concluded that during low turbulent kinetic energy conditions in the Rhine outflow area, tidal straining and frontal circulation determined phytoplankton distribution. At high turbulent kinetic energy, input (from strong winds and spring tide) enhanced the conditions for growth, which resulted in a phytoplankton bloom, i.e. an increase in phytoplankton biomass.

The proposed hypothesis for phytoplankton growth and distribution, in this region, has several caveats generated from insufficient data, mainly that of alongshore phytoplankton distribution and nutrient availability. The incomplete chlorophyll data set does not preclude the idea that the increase in chlorophyll-a could be due to advection of a patch of phytoplankton transported from the north by the winds. While it is difficult to assess any nutrient limitation factor, previous studies 
indicated that waters were nutrient-enriched and mainly riverine in origin (Simpson et al., 1993). This enrichment factor and the possibility that these nutrients could be advected offshore by upwelling winds, together with the fact that the dominant phytoplankton species is a diatom that can withstand high TKE levels, is encouraging in supporting this hypothesis.

The challenge is then put to the modellers to use existing environmental models and try to simulate these results. It would be possible to test different limiting processes, such as nutrients or light, as well as being able to include advective processes allowing phytoplankton to be transported, hence prove or disprove this hypothesis. Preliminary results (Smith, 1996) using MUROFI (Luyten et al., 1994) are in agreement with these conclusions.

\section{Acknowledgements}

This study has been carried out as part of the EC MAST PROFILE project (Contract MAS2CT930054). We gratefully acknowledge Louis Peperzak for providing the unpublished data on phytoplankton species composition and settling velocities. Furthermore we would like to thank the captain and crew of R.V. "Mitra" and Nigel Matthers of UCNW for their co-operation during the SEAROVER survey. Thanks are due to Ceddy Heins who processed the ADCP data and made the time-series plots. Also we would like to thank the valuable comments of two referees about light and nutrient limitation.

\section{References}

Bauer, J., Fischer, J., Leach, H., Woods, J., 1985. SEAROVER Data Report I North Atlantic Summer 1981 — NOA '81. Berichte aus dem Institut Für Meereskunde an der Christian-Albrechts-Universität Kiel, No. 143.

Bienfang, P.K., 1981. SETCOL - A technologically simple and reliable method for measuring phytoplankton sinking rates. Canadian Journal of Fisheries and Aquatic Sciences 38, 1289-1294.

De Ruijter, W.P.M, Van der Giessen, A., Groenendijk, F.C., 1992. Current and density structure in the Netherlands coastal zone. In: Prandle, D. (Ed.), Dynamics and Exchanges in Estuaries and the Coastal Zone, Coastal and Estuarine Studies, Vol. 40. AGU, Washington, DC, pp. 529-550.

Fransz, H.G., 1986. Effects of freshwater inflow on the distribution, composition and production of plankton in the Dutch coastal waters in the North Sea. In: Skreslet, S. (Ed.), The Role of Freshwater Outflow in Coastal Marine Ecosystems. Springer, Berlin, pp. 241-249.

Gieskes, W.W.C., Kraay, G.W., 1984. Phytoplankton, its pigments and primary production at a central North Sea station in May, July and September 1981. Netherlands Journal of Sea Research 18, 51-70.

Jago, C.F., Bale, A.J., Green, M.O., Howarth, M.J., Jones, S.E., McCave, I.N., Millward, G.E., Morris, A.W., Rowden, A.A., Williams, J.J., 1993. Resuspension processes and seston dynamics, southern North Sea. Philosophical Transactions of the Royal Society A 343, 475-491.

Koseff, J.R., Holen, J.K., Moninsmith, S.G., Cloern, J.E., 1993. Coupled effects of vertical mixing and benthic grazing on phytoplankton populations in shallow, turbid estuaries. Journal of Marine Research 51, 843-868.

Luyten, P.J, Ruddick, K.G., Deelersnijder, E., 1994. Documentation on the three-dimensional model MUROFI: first version. Technical Report \#1, MAST-CT93-0054 PROFILE. Management Unit of Mathematical Models of the North Sea and Schelt Estuary (MUMM), Belgium, 81pp.

Malej, A., Mozetic, P., Malacic, V., Terzic, S., Ahel, M., 1995. Phytoplankton responses to freshwater inputs in a small semi-enclose gulf (Gulf of Triestre, Adriatic Sea). Marine Ecological Progress Series 120, 111-121.

Mills, D.K., Tett, P.B., 1990. Use of a recording fluorometer for continuous measurements of phytoplankton concentration. In: Nielsen, H.O. (Ed.), Environment and Pollution Measurement Sensors and Systems. Proceedings 
of the Society of Photo-Optical Instrumentation Engineers, 14-15 March, The Hague, Netherlands, SPIE Proceedings, Vol. 1269, SPIE, Bellingham, pp. 106-115.

Schaub, B.E.M., Gieskes, W.C.C., 1991. Eutrophication of the North Sea: the relation between Rhine river discharge and chlorophyll-a concentration in Dutch coastal waters. In: Elliot, M., Ducrotoy, J.P. (Eds.), Estuaries and Coasts: Spatial and Temporal Intercomparisons. ECSA 19 Symposium, pp. 85-90.

Simpson, J.H., Bowers, D., 1981. Models of stratification and frontal movements in the shelf seas. Deep-Sea Research 28A, 727-738.

Simpson, J.H., Bos, W.G., Shirmer, F., Souza, A.J., Rippeth, T.P., Jones, S.E., Hydes, D., 1993. Periodic stratification in the Rhine ROFI in the North Sea. Oceanologica Acta 16 (1), 23-32.

Simpson, J.H., Souza, A.J., 1995. Semi-diurnal switching of stratification in the region of freshwater influence (ROFI) of the Rhine. Journal of Geophysical Research 100, 7037-7044.

Smith, C., 1996. Calculations of initial and boundary conditions for 1-D and 3-D versions of MUROFI from measurements made during the Rhine Plume experiment (March-October, 1994). Working document, UWB, School of Ocean Sciences, $16 \mathrm{pp}$.

Souza, A.J., James, I.D., 1996. A two-dimensional model of tidal straining in the Rhine ROFI. Continental Shelf Research 16, 949-966.

Tett, P.B., Joint, I.R., Purdie, D.A., Baars, M., Oosterhuis, S., Danieri, G., Hannah, F., Mills, D.K., Plummer, D., Pomroy, A.J., Walne, A.W., Witte, H.J., 1993. Biological consequences of tidal stirring gradients in the North Sea. Philosophical Transactions of the Royal Society A 343, 493-508.

Van Alphen, J.S.L.J., De Ruijter, W.P.M., Borst, J.C., 1988. Outflow and three-dimensional spreading of Rhine river water in the Netherlands coastal zone. In: Dronkers, J., van Leussen, W. (Eds.), Physical Processes in Estuaries. Springer, Berlin, pp. 70-92.

Van der Giessen, A., De Ruijter, W.P.M., Borst, J.C., 1990. Three-dimensional current structure in the Dutch coastal zone. Netherlands Journal of Sea Research 25, 45-55.

Visser, A.W., Souza, A.J., Hessner, K., Simpson, J.H., 1993. The influence of water column stratification on tidal current profiles in a ROFI system. Oceanologica Acta 17, 369-381.

Visser, M., 1993. On the transport of fine marine sediment in the Netherlands coastal zone. Thesis, Universiteit Utrecht, ISBN 90-393-0129-8.

Zevenboom, W., Rademaker, M., Colijn, F., 1991. Exceptional algal blooms in Dutch North Sea waters. Water Science and Technology 24, 251-260. 